\title{
Money Doctors and Latin American Central Banks at the Onset of the Great Depression
}

\author{
Juan Flores Zendejas* (D) \\ Associate Professor, Paul Bairoch Institute of Economic History, University of Geneva, and Professor by \\ Courtesy at Centro de Investigación y Docencia Económicas, Mexico City \\ ${ }^{*}$ Corresponding author. Email: juan.flores@unige.ch
}

(Received 19 June 2019; revised 16 February 2021; accepted 26 February 2021;

first published online 15 June 2021)

\begin{abstract}
Many of today's central banks in Latin America were established in the interwar period. During the 1920s, most of them were designed under the influence of money doctors. The main mandate of these new institutions was to cope with inflation and provide exchange stability. This article analyses how these central banks responded to the onset of the Great Depression. I show that, in accordance with the requirements of the monetary regime, central banks initially acted to prevent capital outflows and to protect their gold reserves. This led to a credit drop to the private sector. Additional credit was made available once governments decided to intervene more actively in the economy, thereby disregarding the advice of money doctors. The central banks that were founded in the 1930s, and the reforms introduced to those already operating, were conceived to face the effects of the crisis.
\end{abstract}

Keywords: central banking; Great Depression; gold standard; money doctors; financial crises

\section{Introduction}

In 1934, five years after the onset of the Great Depression, Raúl Prebisch submitted a proposal for setting up a central bank in Argentina. ${ }^{1}$ One of its main aims was to furnish the proposed central bank with a blueprint for a more proactive monetary policy. The proposal covered banking supervision and rediscount operations, and provided a strategic plan for addressing the ongoing liquidity problems faced by Argentina's commercial banks. In doing so, Prebisch laid out some of his preliminary thinking on the role of counter-cyclical economic policies in peripheral economies such as Argentina's. Thus, the establishment of the Banco Central de la República Argentina (Central Bank of the Argentine Republic, BCRA) in 1935 illustrated the passage to a new era in the development of monetary policy in Latin America.

\footnotetext{
${ }^{1}$ Prebisch worked in the Banco de la Nación Argentina (Bank of the Argentine Nation, BNA) (1927-35), and had been undersecretary of finance (1930-2) and counsellor to the Ministry of Finance and the Ministry of Agriculture (1933).

(c) The Author(s), 2021. Published by Cambridge University Press. This is an Open Access article, distributed under the terms of the Creative Commons Attribution licence (https://creativecommons.org/licenses/by/4.0/), which permits unrestricted re-use, distribution, and reproduction in any medium, provided the original work is properly cited.
} 
Argentina had decided against establishing a central bank in the 1920s. Nevertheless, the country shared many of the economic problems faced by other countries in the region that had determined to found central banks during that decade. Prebisch's proposal broke with the received orthodoxy that had hitherto guided the formation of other central banks in Latin America, which had been set up in tandem with a range of fiscal and monetary reforms. In Colombia (1923), Chile (1925), Ecuador (1926), Bolivia (1927) and Peru (1931), such reforms took place on the advice of Edwin Walter Kemmerer, a professor of economics and international finance at the University of Princeton, in his capacity as a foreign advisor. It was hoped that his reforms would contribute to the formation of a stable monetary system based on the gold standard, which would boost economic recovery by expanding domestic credit, encouraging foreign investment and enhancing access to international capital markets.

The first years of the implementation of Kemmerer's reforms were successful. Local currencies were stabilised and government loans were issued in New York and London. These external funds served to bolster the reserves of the new central banks and provided finance for infrastructure projects. Nevertheless, domestic credit remained low, and the new monetary system soon began to show its flaws. While the squeeze on credit was a direct consequence of the deflationary policies introduced to meet the requirements of pegging the currency to the gold standard, the crisis that started in 1929 aggravated the credit shortage in key sectors such as agriculture and industry. Moreover, although most of the central banks recognised the need to act as a lender of last resort, being tied to the gold standard constrained their capacity to offer financial support to commercial banks.

This article analyses the transition from the first to the second generation of Latin American central banks (those established in the 1930s) and presents a comparative analysis of the changes that occurred across the region during this period. Previously, the literature has been focused either on the reforms introduced by money doctors, ${ }^{2}$ or on the case of individual nations. ${ }^{3}$ However, a regional comparison of the history of central banking in the interwar period can yield interesting insights. Overall, I observe that the role of central banks in the economy became one in which credit provision was a central concern, along with the capacity to introduce counter-cyclical monetary policies. While the Great Depression triggered this shift, the economic fragilities that would motivate it - along with new ideas on the role of monetary policy in the economy - had been present earlier in the 1920s in almost every country analysed.

The extensive literature on the gold standard has shown that poor economic performance together with a change of thinking and the weakening of the 'good housekeeping seal of approval' were the main factors that prompted governments to leave

\footnotetext{
${ }^{2}$ 'Money doctors' are agents that provide expert economic advice to foreign governments. See Marc Flandreau, Money Doctors: The Experience of International Financial Advising, 1850-2000 (London: Routledge, 2003).

${ }^{3}$ Two important exceptions are Carlos Díaz-Alejandro, Latin America in the 1930s (New Haven, CT: Economic Growth Center, Yale University, 1982) and Luis Ignacio Jácome, Central Banking in Latin America, IMF Working Papers (Washington, DC: IMF, 2015).
} 
this monetary regime. ${ }^{4}$ I show that it was the urgent need to facilitate credit - both to the government and to the private sector - that was the major factor in many instances in Latin America. It is also significant that many governments began to express misgivings about their capacity to secure foreign financial support. As I show below, the countries where Kemmerer's policies were implemented appear to have been the most committed to the monetary and fiscal orthodoxy of the 1920 s, despite the severity of the economic crisis.

Finally, I analyse the consolidation of proactive monetary policies as governments responded to problems that had been present even before the crisis. I provide a comparison between the central banks founded under the advice of Kemmerer and those proposed by Otto Niemeyer, the British foreign advisor to Argentina and Brazil in the 1930s. I observe similarities but also relevant contrasts between Kemmerer's and Niemeyer's proposed central banks, even though both supported orthodox monetary policies. These were different from Prebisch's proposal, whose approach was finally adopted in Argentina. I also show that Prebisch's project was in line with the monetary policies and central banks' reforms being independently introduced in other countries such as Chile and Mexico. While this new design of central banking was also the one preferred in Venezuela by the end of the decade, El Salvador's previous experience shows that the paradigm shift was not complete.

\section{Money Doctors and Economic Policies in Latin America}

There is a large body of literature on the influence of money doctors on the economic policies in Latin America. Emily Rosenberg and Norman Rosenberg argue that financial advising emerged as an alternative to US colonialism, and served to facilitate the expansion of US investment and trade in the late nineteenth and early twentieth centuries. ${ }^{5}$ By resorting to private contracting in the sphere of foreign lending, the United States could exert an important influence on Latin American economic policies. The US government initially sent financial advisors to two US protectorates, the Philippines and Puerto Rico, followed by other countries in the Caribbean and Central America as a result of the 1904 Roosevelt Corollary to the Monroe Doctrine, which was intended to mitigate European influence in the zone. In countries such as Panama and the Dominican Republic, the establishment of a stable currency system closely linked to the US dollar was prioritised by the US government.

A main controversy concerns the role of foreign advisors as promoters of the foundation of central banks in the region. Rosenberg claims that the systems implemented, based on a gold-exchange standard, did not necessarily foresee the establishment of central banks. ${ }^{6}$ In Central America, Victor Bulmer-Thomas explains that Nicaragua established its national bank in 1912. The government also

\footnotetext{
${ }^{4}$ A summary of this literature can be found in Holger Wolf and Tarik Yousef, 'Breaking the Fetters: Why Did Countries Exit the Interwar Gold Standard?' in Timothy J. Hatton et al., The New Comparative Economic History: Essays in Honor of Jeffrey G. Williamson (Cambridge, MA: MIT Press, 2007).

${ }^{5}$ Emily S. Rosenberg and Norman L. Rosenberg, 'From Colonialism to Professionalism: The PublicPrivate Dynamic in United States Foreign Financial Advising, 1898-1929', Journal of American History, 74: 1 (1987), pp. 59-82.

${ }^{6}$ Emily S. Rosenberg, 'Foundations of United States International Financial Power: Gold Standard Diplomacy, 1900-1905', Business History Review, 59: 2 (1985), pp. 169-202.
} 
appointed a US collector-general and introduced a new monetary system based on a gold-exchange standard. ${ }^{7}$ In contrast, this author describes how Arthur Young, the US financial advisor appointed by the Honduras government in 1921, also recommended the adoption of a gold-exchange standard but without including a central monetary authority in his proposal. The government preserved a double regime (gold and silver standards) although maintaining a fixed exchange rate with the dollar.

In the Andean countries, Paul W. Drake provides a comprehensive narrative on Kemmerer's role as the money doctor who recommended the establishment of central banks in the 1920s. ${ }^{8}$ This author suggests that a main reason for the establishment of central banks in Latin America was local politicians' desire to imitate the monetary organisation of the United States, whose Federal Reserve System had only been established in 1913. Another relevant reason was the belief that following Kemmerer's recommended economic policies would boost the volume of foreign investment in their countries. Barry Eichengreen confirms that the presence of money doctors and the monetary stabilisation that followed also led to an expansion of foreign lending in the region. ${ }^{9}$

The literature also disagrees on the role of foreign advisors in the aftermath of the Great Depression. As we shall see, money doctors continued to be present in various Latin American countries. British money doctors became the main protagonists, as trading connections with Britain remained strong and governments continued to look for external advice. Argentina, for example, was still strongly dependent upon Britain both as an export market and as a creditor. ${ }^{10}$ Richard Sidney Sayers argues that the Board of Trade and the Foreign Office wished to maintain British trade and influence in South America. However, money doctors' recommendations seem to have lost the relevance they had acquired in the previous decade. Two of the most quoted cases are Brazil and Argentina. ${ }^{11}$ In 1931, Brazil's government appealed to Niemeyer, from the Bank of England, after a severe fall in the Banco do Brasil (Bank of Brazil)'s gold reserves and with the aim of receiving additional external funding. Niemeyer was expected to provide policy recommendations, predominantly with regard to monetary stability and the establishment of a central bank. ${ }^{12}$ Winston Fritsch suggests that Niemeyer's recommendations failed to be implemented because the government perceived that no foreign loans could be obtained. ${ }^{13}$

\footnotetext{
${ }^{7}$ Victor Bulmer-Thomas, The Political Economy of Central America Since 1920 (Cambridge: Cambridge University Press, 1987).

${ }^{8}$ Paul W. Drake (ed.), Money Doctors, Foreign Debts, and Economic Reforms in Latin America from the 1890s to the Present (Wilmington, DE: SR, 1994).

${ }^{9}$ Barry Eichengreen, 'House Calls of the Money Doctor: The Kemmerer Missions to Latin America, 1917-1931', in ibid., pp. 110-32.

${ }^{10}$ Arturo O'Connell, 'Free Trade in One (Primary Producing) Country: The Case of Argentina in the 1920s', in Guido di Tella and Desmond Christopher Martin Platt (eds.), The Political Economy of Argentina, 1880-1946 (New York: St Martin's Press, 1986), pp. 74-94.

${ }^{11}$ Richard Sidney Sayers, The Bank of England: 1891-1944 (Cambridge and New York: Cambridge University Press, 1976), p. 522.

${ }^{12}$ Marcelo de Paiva Abreu, 'A missão Niemeyer', Revista de Administração de Empresas, 14: 4 (1974), pp. 7-28.

${ }^{13}$ Winston Fritsch, External Constraints on Economic Policy in Brazil, 1889-1930 (Pittsburgh, PA: University of Pittsburgh Press, 1988).
} 
In Argentina, the government decided to establish a central bank in 1935, as advised by Niemeyer's mission one year earlier. However, the final result has created some controversies in the literature. Sayers suggests that the structure of Argentina's central bank was close to the recommendations made by Niemeyer, ${ }^{14}$ while, according to Florencia Sember, Niemeyer's proposal was profoundly divergent from the one finally adopted, following rather Prebisch's concept of a central bank. ${ }^{15}$ These differences concerned the autonomy of the bank, the composition of its directive board, its supervisory responsibilities, its main purposes and the convertibility of its currency. In particular, Sember claims that a main priority of Niemeyer's project of a central bank was the regulation of the volume of credit and the consequent demand for money in order to maintain the external value of the peso as assigned to it by law. However, the final project prioritised the central bank's capacity to mitigate the consequences of fluctuations in exports and foreign capital investment on money, credit and commercial activities, while maintaining the value of money. These targets were expected to be met through the restriction of credit and the accumulation of gold and currency reserves during the ascending phase of the cycle, so that these could be used during the downward phase.

\section{The Advent of Latin America's Central Banks}

In the aftermath of the Great War, the state of banking development in Latin America varied according to the economic requirements of each country and their institutional and political stability. ${ }^{16}$ In Argentina, Uruguay, Chile and Costa Rica, foreign and domestic banks had assumed a prominent role in the credit market, attracting high levels of deposits and channelling capital to domestic ventures and the financing of international trade. ${ }^{17}$ In Brazil, Bolivia, Ecuador and Mexico, government intervention (i.e. inflationary financing) and political instability had impeded the development of the banking sector. In Mexico, the Mexican Revolution had forestalled the development of banks, contributing to low economic growth in its aftermath. ${ }^{18}$ In Brazil, the level of domestic credit had fluctuated before plummeting in the first decades of the twentieth century. In 1929, it plunged to 6 per cent of total GDP, estimated to be one of the lowest figures on record in the modern world. ${ }^{19}$

\footnotetext{
${ }^{14}$ Sayers, The Bank of England, p. 524.

${ }^{15}$ Florencia Sember, 'Challenging a Money Doctor: Raúl Prebisch vs Sir Otto Niemeyer on the Creation of the Argentine Central Bank', Research in the History of Economic Thought and Methodology, 36 (Nov. 2018), pp. 55-79.

${ }^{16}$ For a recent analysis on banking history in Latin America, see Daniel Díaz Fuentes, Andrés Hoyo Aparicio and Carlos Marichal, Orígenes de la globalización bancaria: Experiencias de España y América Latina (Santander: Genueve Ediciones, 2017).

${ }^{17}$ I estimated an indicator on financial development based on deposits per capita in 1922. Argentina's figure was by far the highest (US\$128), followed by Uruguay (US\$55.6) and Chile (US\$41.6). Ecuador had the lowest with US\$2.6. Sources are International Statistical Yearbook of the League of Nations (Geneva: League of Nations, Economic and Financial Section, 1922) and the Montevideo-Oxford Latin American Economic History Database (MOxLAD) for data on population.

${ }^{18}$ Stephen H. Haber, 'Mercado interno, industrialización y banca, $1890-1929$ ', in Sandra Kuntz Ficker (ed.), Historia económica general de México: De la colonia a nuestros días (Mexico City: El Colegio de México, Secretaría de Economía, 2010), pp. 411-36.

${ }^{19}$ Aldo Musacchio, Experiments in Financial Democracy: Corporate Governance and Financial Development in Brazil, 1882-1950 (New York: Cambridge University Press, 2009).
} 
Along with political instability, macroeconomic volatility affected the region's economic performance. By the end of the nineteenth century, most Latin American countries had adopted the gold standard, only to abandon it at the onset of the First World War. Then, during the 1920s, Latin American governments started to succumb to the pressure to return to the gold standard in order to achieve monetary stabilisation. This followed discussions at the International Financial Conferences of Brussels and Genoa of 1920 and 1922 respectively, where it had been agreed that a new monetary system - the gold-exchange standard - would be adopted. ${ }^{20}$ Because the pound sterling and the US dollar were expected to be convertible to gold at a stable rate of exchange, they could serve as the reserve currencies that could substitute for pure gold reserves. In this system, the exchange rates and, therefore, the value of national currencies, had to be stabilised by central banks. These institutions were established around the world with the aim of reorganising financial and foreign exchange systems and encouraging adherence to the gold standard. ${ }^{21}$

The establishment of central banks in Latin America generated heated debates. In countries in which state banks had close relationships with their national governments and enjoyed a monopoly for issuing banknotes, there was strong resistance to the establishment of central banks. ${ }^{22}$ Such were the cases of Argentina, Brazil and Mexico. In Argentina, the Banco de la Nación Argentina (Bank of the Argentine Nation, BNA) allied itself with the political party that had been opposed to the creation of a central bank in $1917 .^{23}$ In Brazil, Banco do Brasil was a state bank with privileges that boosted its profitability, such as its capacity for multi-branching; given that the Brazilian Federal State was its main owner, this was of benefit to the government. ${ }^{24}$ In Mexico, the Banco Nacional de México (National Bank of Mexico) had traditionally acted as the government bank and sought to become the new central bank. It was adversely affected by the government's decision to establish a new institution in 1925, with the new central bank being seen as enjoying too much proximity to the government. ${ }^{25}$ Mexican banking legislation did not require mandatory association with the central bank, and, as a result, initially only two banks chose to become associate banks, reaching five banks by $1929 .{ }^{26}$

\footnotetext{
${ }^{20}$ Michel Fior, Institution globale et marchés financiers: La Société des Nations face à la reconstruction de l'Europe, 1918-1931 (Bern: P. Lang, 2008).

${ }^{21}$ Among the resolutions unanimously approved by the Brussels International Financial Conference, one reads: 'In countries where there is no Central Bank of Issue, one should be established' (Resolution proposed by the 14th Commission on Currency and Exchange). See League of Nations, Brussels Financial Conference, 1920: The Recommendations and Their Application; A Review after Two Years (Geneva: League of Nations, 1923), Annex I, p. 225.

${ }^{22}$ State banks were institutions under state control. They could serve as commercial banks, governments' fiscal agents and banks of issue. A central bank was mainly responsible for a country's monetary policy.

${ }^{23}$ Mario Rapoport, Historia económica, política y social de la Argentina (1880-2003) (Buenos Aires: Ariel, 2006).

${ }^{24}$ André Villela, 'Las funciones de banca central antes del banco central: El caso del Banco de Brasil', in Díaz Fuentes et al., Orígenes de la globalización bancaria, pp. 437-57.

${ }^{25}$ Aurora Gómez-Galvarriato, 'La etapa inicial del Banco Central: Creación, consolidación y crisis, 1925-1932', in Leonor Ludlow and María Eugenia Romero Sotelo, El Banco de México a través de sus constructores, 1917-2017 (Mexico City: UNAM, 2019), pp. 223-54.

${ }^{26}$ Associated banks were those having acquired a minimum number of central banks' shares, and were thus entitled to pursue a set of operations with the central bank.
} 
In Chile, the debate concerned the diagnosis of Chile's monetary problems and whether the establishment of a central bank was desirable at all. Those who wanted to establish a central bank with strict rules determined by the gold standard were opposed by those who feared the rigidity of this type of monetary system. ${ }^{27}$ Chile's president, Arturo Alessandri, invited Kemmerer to visit in 1922. However, Alessandri was ousted by a military coup two years later. The new de facto government intended to carry out the ongoing financial reforms without continuing parliamentary debate. It is interesting to note that this decision met with little public disapproval. Monetary instability and inflation had already sparked public protest, and Kemmerer's mission was apparently welcomed by many, including the working class. Indeed, labour unions considered that a central bank could halt inflation and improve earnings. ${ }^{28}$

Similar attitudes prevailed elsewhere. In Bolivia, the media referred to Kemmerer as 'the magician of world finances' and several articles outlined the benefits that would stem from the proposed financial reforms. ${ }^{29}$ In Colombia, in spite of criticism from the nationalist parties, the most important parties in Parliament welcomed Kemmerer's project. The generally positive reaction derived from the widespread belief that new financial institutions and legislation would serve to bolster the purchasing power of the local currency. ${ }^{30}$ In Ecuador, where prices had been volatile in the years prior to Kemmerer's arrival, several favourable articles were published in the press during the course of $1927 . .^{31}$

By contrast, there were those who rejected Kemmerer's proposals. Exporting elites and large landholders were opposed to the introduction of a gold standard, given that currency depreciation could be so advantageous to them; Bolivian mine owners are an example. ${ }^{32}$ In countries such as Bolivia and Colombia, where commercial banknotes had been issued by several private banks, the prospect of centralising this highly profitable activity was met with general opposition. In Ecuador, the proposed reforms caused severe disagreement among groups of regional bankers who held differing views and interests in the country's monetary policy. Nevertheless, after several years of high inflation, the first steps towards the centralisation of reserves and restriction of the capacity to issue currency were undertaken prior to the arrival of Kemmerer through the founding of an institution

\footnotetext{
${ }^{27}$ Edwin Walter Kemmerer, 'Economic Advisory Work for Governments', The American Economic Review, 17: 1 (1927), pp. 1-12; Camilo Carrasco, Banco Central de Chile, 1925-1964: Una historia institucional (Santiago: Banco Central de Chile, 2009).

${ }^{28}$ Paul W. Drake, The Money Doctor in the Andes: The Kemmerer Missions, 1923-33 (Durham, NC: Duke University Press, 1989), p. 76.

${ }^{29}$ Superintendencia de Bancos y Entidades Financieras, Regulación y supervisión financiera en Bolivia, 1928-2003 (La Paz: Superintendencia de Bancos y Entidades Financieras, 2003).

${ }^{30}$ A summary of the press articles referring to Kemmerer's first mission in Colombia can be found in Edwin Walter Kemmerer, Kemmerer y el Banco de la República: Diarios y documentos (Bogotá: Banco de la República, 1994).

${ }^{31}$ Rebeca Almeida, Kemmerer en el Ecuador (Quito: FLACSO, 1994); Carlos Marchán Romero, Historia del Banco Central del Ecuador: De banco de gobierno a banco emisor y vuelta al pasado (1927-2000) (Quito: Banco Central del Ecuador, 2005). In general, inflation declined in the countries visited by Kemmerer.

${ }^{32}$ Drake, The Money Doctor in the Andes, p. 182.
} 
called Caja Central de Emisión y Amortización (Central Office for Note Issue and Withdrawal). ${ }^{33}$

Domestic coalitions, mainly formed by importers, merchants and consumers hoping to benefit from an increase in credit and a decline in interest rates, initially supported Kemmerer's reforms but began to oppose them as implementation progressed. Drake reports that in all the Andean countries visited by Kemmerer, the major problem was the scarcity and high cost of credit. ${ }^{34}$ The agriculturalists and industrialists believed that central banks could play a similar role to today's development banks by granting long-term loans, something to which Kemmerer was consistently opposed, as he believed that these should be provided by mortgage and commercial banks. ${ }^{35}$ In what follows, I describe the features of the new central banks and the criticism they provoked during the first years of their existence.

\section{Central Banking and Monetary Policy: A General Overview Constitution of the New Central Banks}

There were eight central banks established in Latin America between 1922 and 1931. I show their structure and management in Table 1. In five cases, Kemmerer was the main designer of these new institutions (hence the term 'Kemmerer countries'), which were created along with new fiscal, banking and monetary legislation in each country. Table 1 includes the ambivalent cases of Mexico and Guatemala, as well as the first central bank of Peru. Kemmerer's mission in Mexico had resulted in a plan to found a central bank in 1917, although the Banco de México (Bank of Mexico) was not established until 1925 and, while it remained close to his original proposal, certain differences could be observed: the proposal had envisaged a mixed private-public ownership, whereas the final version was exclusively publicly owned; ${ }^{36}$ the central bank managed the exchange rate while, very briefly, operating in a gold-exchange regime in tandem with the Ministry of Finance, with whom it shared the responsibility for monetary policy, a feature unforeseen in the original proposal. Despite these differences, contemporaries depicted the creation and evolution of the Banco de México during its first years of existence as following 'Kemmerer lines.'.

The only country from Central America represented in Table 1 is Guatemala. Kemmerer visited that country in 1919, even though the final legislation was only implemented seven years later under Enrique Martínez Sobral, who had

\footnotetext{
${ }^{33}$ Cristian Paúl Naranjo Navas, 'Fundación del Banco Central del Ecuador', in Carlos Marichal and Thiago Fontelas Rosado Gambi, Histoira bancaria y monetaria de América Latina (siglos XIX y XX): Nuevas perspectivas (Santander: Ediciones Universidad Cantabria, 2017), pp. 397-428.

${ }^{34}$ Drake, The Money Doctor in the Andes, p. 129.

${ }^{35}$ See the discussion of the banking law in Ecuador, in 'Economic Conferences, Sessions 8, February 26 1926 and March 7 1926', Seeley G. Mudd Manuscript Library at Princeton University (henceforth SGMML), Edwin W. Kemmerer Papers (henceforth EKP), box 154, folder 1.

${ }^{36}$ For a detailed comparison, see Gianandrea Nodari, "Putting Mexico on Its Feet Again": The Kemmerer Mission in Mexico, 1917-1931', Financial History Review, 26: 2 (2019), pp. 223-46.

${ }^{37}$ 'The Bank of Mexico', 15 Aug. 1933, Bank of England Archives (henceforth BoEA), file OV166/7.
} 
Table 1. Central Banks Established during the 1920s: Kemmerer and 'Kemmererised' Central Banks

\begin{tabular}{|c|c|c|c|c|c|c|c|c|}
\hline & $\begin{array}{c}\text { Peru } \\
9 \text { March } 1922\end{array}$ & $\begin{array}{l}\text { Colombia } \\
11 \text { July } 1923\end{array}$ & $\begin{array}{c}\text { Chile } \\
21 \text { August } 1925\end{array}$ & $\begin{array}{c}\text { Mexico } \\
1 \text { September } \\
1925\end{array}$ & $\begin{array}{c}\text { Guatemala } \\
11 \text { December } \\
1926\end{array}$ & $\begin{array}{c}\text { Ecuador } \\
4 \text { March } 1927\end{array}$ & $\begin{array}{c}\text { Bolivia } \\
20 \text { July } 1928\end{array}$ & $\begin{array}{c}\text { Peru } \\
18 \text { April } 1931\end{array}$ \\
\hline \multicolumn{9}{|l|}{ Authorised capital } \\
\hline $\begin{array}{l}\text { (in millions local } \\
\text { currency) }^{\mathrm{a}}\end{array}$ & 2 & 10 & 150 & 100 & 10 & 10 & 30 & 30 \\
\hline (in million dollars) & 7.5 & 9.5 & 17.4 & 49.4 & 10 & 1.9 & 10.6 & 8.4 \\
\hline $\begin{array}{l}\text { Duration } \\
\quad \text { (in years) }\end{array}$ & 25 & 20 & 50 & 30 & 30 & 50 & 50 & 30 \\
\hline \multicolumn{9}{|l|}{ Shareholding } \\
\hline $\begin{array}{l}\text { Total number of } \\
\text { shares }\end{array}$ & 200,000 & 100,000 & 150,000 & 1 million & 1 million & 100,000 & 300,000 & 300,000 \\
\hline State & 0 & 5 million & 20 million & At least $51 \%$ & No imposition & No imposition & No imposition & No imposition \\
\hline Domestic banks & $\begin{array}{l}10 \% \text { of their } \\
\text { capital; } 0.5 \\
\text { million Peruvian } \\
\text { pounds }\end{array}$ & $\begin{array}{l}15 \% \text { of their } \\
\text { capital and } \\
\text { reserves }\end{array}$ & $\begin{array}{c}10 \% \text { of their capital } \\
\text { and reserves }\end{array}$ & $\begin{array}{l}6 \% \text { of their } \\
\text { capital and } \\
\text { reserves }\end{array}$ & Not specified & $\begin{array}{l}15 \% \text { of their capital } \\
\text { and reserves }\end{array}$ & $\begin{array}{c}\text { 'Associate } \\
\text { banks' } 15 \% \text { of } \\
\text { their capital and } \\
\text { reserves }\end{array}$ & $\begin{array}{l}10 \% \text { of their } \\
\text { capital and } \\
\text { reserves }\end{array}$ \\
\hline Foreign banks & $\begin{array}{l}10 \% \text { of their } \\
\text { capital; } 0.5 \\
\text { million Peruvian } \\
\text { pounds }\end{array}$ & $\begin{array}{l}15 \% \text { of their } \\
\text { capital and } \\
\text { reserves }\end{array}$ & $\begin{array}{l}10 \% \text { of their capital } \\
\text { and reserves }\end{array}$ & $\begin{array}{l}6 \% \text { of their } \\
\text { capital and } \\
\text { reserves }\end{array}$ & Not specified & $\begin{array}{l}15 \% \text { of their capital } \\
\text { and reserves }\end{array}$ & $\begin{array}{l}15 \% \text { of their } \\
\text { capital and } \\
\text { reserves }\end{array}$ & $\begin{array}{l}10 \% \text { of their } \\
\text { capital and } \\
\text { reserves }\end{array}$ \\
\hline Other & $\begin{array}{c}0.5 \text { million } \\
\text { Peruvian } \\
\text { pounds offered } \\
\text { to the public. No } \\
\text { vote }\end{array}$ & $\begin{array}{l}\text { Any individual } \\
\text { or enterprise. } \\
\text { They give a } \\
\text { right to vote } \\
\text { only if they } \\
\text { reach } 500,000 \\
\text { gold pesos. }\end{array}$ & $\begin{array}{l}\text { Shares offered to } \\
\text { individuals and } \\
\text { firms if total } \\
\text { amount of capital } \\
\text { below } 150 \text { million }\end{array}$ & $\begin{array}{l}\text { Shares 'B' can } \\
\text { be subscribed } \\
\text { by the } \\
\text { government or } \\
\text { the general } \\
\text { public }\end{array}$ & $\begin{array}{l}\text { The shares are } \\
\text { offered to the } \\
\text { general public }\end{array}$ & $\begin{array}{l}\text { Shares 'B' offered to } \\
\text { the general public }\end{array}$ & $\begin{array}{l}\text { Shares ' } C \text { ' } \\
\text { offered to the } \\
\text { general public }\end{array}$ & $\begin{array}{c}\text { Shares 'B' offered } \\
\text { to the general } \\
\text { public }\end{array}$ \\
\hline
\end{tabular}


Table 1. (Continued.)

\begin{tabular}{|c|c|c|c|c|c|c|c|c|}
\hline & $\begin{array}{c}\text { Peru } \\
9 \text { March } 1922\end{array}$ & $\begin{array}{l}\text { Colombia } \\
11 \text { July } 1923\end{array}$ & $\begin{array}{c}\text { Chile } \\
21 \text { August } 1925\end{array}$ & $\begin{array}{c}\text { Mexico } \\
1 \text { September } \\
1925\end{array}$ & $\begin{array}{c}\text { Guatemala } \\
11 \text { December } \\
1926\end{array}$ & $\begin{array}{c}\text { Ecuador } \\
\text { 4 March } 1927\end{array}$ & $\begin{array}{c}\text { Bolivia } \\
20 \text { July } 1928\end{array}$ & $\begin{array}{c}\text { Peru } \\
18 \text { April } 1931\end{array}$ \\
\hline \multicolumn{9}{|l|}{ Board of directors } \\
\hline Presidency & $\begin{array}{l}\text { President, } \\
\text { vice-president } \\
\text { elected by } \\
\text { board }^{\mathrm{c}}\end{array}$ & $\begin{array}{l}\text { Manager and } \\
\text { assistant } \\
\text { manager } \\
\text { elected by } \\
\text { board }\end{array}$ & $\begin{array}{c}\text { President, } \\
\text { vice-president and } \\
\text { manager elected by } \\
\text { board }\end{array}$ & $\begin{array}{l}\text { Director elected } \\
\text { by board }\end{array}$ & $\begin{array}{c}\text { Manager and } \\
\text { assistant } \\
\text { manager elected } \\
\text { by shareholders' } \\
\text { General } \\
\text { Assembly }\end{array}$ & $\begin{array}{l}\text { President, } \\
\text { vice-president and } \\
\text { manager elected by } \\
\text { board }\end{array}$ & $\begin{array}{l}\text { President, } \\
\text { vice-president } \\
\text { and manager } \\
\text { elected by } \\
\text { board }\end{array}$ & $\begin{array}{c}\text { President, } \\
\text { vice-president } \\
\text { and manager } \\
\text { elected by board }\end{array}$ \\
\hline $\begin{array}{l}\text { Total number of } \\
\text { members }\end{array}$ & 10 & 9 & 10 & 9 & 9 & 9 & 9 & $10-11$ \\
\hline \multicolumn{9}{|l|}{ Appointed by: } \\
\hline State & 3 & 3 & 3 & 5 & 2 & 2 & 2 & 3 \\
\hline Domestic banks & $4^{d}$ & 2 & 2 & - & 1 & 2 & $\begin{array}{l}2 \text { (appointed by } \\
\text { all associate } \\
\text { banks) }\end{array}$ & 2 \\
\hline Foreign banks & 2 & 1 & 1 & - & 0 & - & - & 1 \\
\hline Agriculture & 0 & $\begin{array}{l}3 \text { (appointed } \\
\text { by domestic } \\
\text { and foreign } \\
\text { banks }^{\mathrm{c}} \text { ) }\end{array}$ & $\begin{array}{l}1 \text { (appointed jointly } \\
\text { by the National } \\
\text { Society of } \\
\text { Agriculture and by }\end{array}$ & 0 & 0 & $\begin{array}{c}1 \text { appointed by the } \\
\text { Chamber of } \\
\text { Commerce and } \\
\text { Agriculture of }\end{array}$ & 1 & $\begin{array}{l}3 \text { (appointed } \\
\text { jointly by } \\
\text { agricultural, } \\
\text { commercial and }\end{array}$ \\
\hline Industry & 0 & - & $\begin{array}{l}\text { the Society for the } \\
\text { Promotion of } \\
\text { Textile Industry) }\end{array}$ & 0 & 0 & $\begin{array}{c}\text { Guayaquil; } 1 \\
\text { appointed by the } \\
\text { Chamber of } \\
\text { Commerce, Agriculture }\end{array}$ & $\begin{array}{l}1 \text { (appointed by } \\
\text { mining } \\
\text { industrialists) }\end{array}$ & $\begin{array}{l}\text { industrial } \\
\text { corporations) }\end{array}$ \\
\hline Commerce & 0 & - & $\begin{array}{c}1 \text { (appointed by the } \\
\text { Chilean } \\
\text { Corporation of } \\
\text { Sales in Saltpetre } \\
\text { and lodine and the } \\
\text { Chilean Central } \\
\text { Chamber of } \\
\text { Commerce) }\end{array}$ & 0 & 0 & $\begin{array}{c}\text { and Industry of Quito; } \\
1 \text { appointed by the } \\
\text { National Society of } \\
\text { Agriculture }\end{array}$ & $\begin{array}{l}1 \text { (National } \\
\text { Chambers of } \\
\text { Commerce) }\end{array}$ & \\
\hline
\end{tabular}


Table 1. (Continued.)

\begin{tabular}{|c|c|c|c|c|c|c|c|c|}
\hline & $\begin{array}{c}\text { Peru } \\
9 \text { March } 1922\end{array}$ & $\begin{array}{c}\text { Colombia } \\
11 \text { July } 1923\end{array}$ & $\begin{array}{c}\text { Chile } \\
21 \text { August } 1925\end{array}$ & $\begin{array}{c}\text { Mexico } \\
1 \text { September } \\
1925\end{array}$ & $\begin{array}{c}\text { Guatemala } \\
11 \text { December } \\
1926\end{array}$ & $\begin{array}{c}\text { Ecuador } \\
4 \text { March } 1927\end{array}$ & $\begin{array}{c}\text { Bolivia } \\
20 \text { July } 1928\end{array}$ & $\begin{array}{c}\text { Peru } \\
18 \text { April } 1931\end{array}$ \\
\hline Trade unions & 0 & 0 & 1 & - & 0 & 1 & - & - \\
\hline Other & 1 (Fiscal agency) & 0 & 1 & $\begin{array}{c}4 \text { (appointed by } \\
\text { 'Serie B' } \\
\text { shareholders) }\end{array}$ & $\begin{array}{c}6 \text { (foreign and } \\
\text { national } \\
\text { shareholders) }\end{array}$ & 1 & 2 (the public) & 1 \\
\hline Reserve requirements & $50 \%$ & $60 \%$ & $50 \%$ & $50 \%$ & $40 \%$ & $50 \%$ & $50 \%$ & $50 \%$ \\
\hline $\begin{array}{l}\text { Limit on government } \\
\text { lending }\end{array}$ & None & $30 \%$ & $30 \%$ & $10 \%$ & $10 \%$ & $20 \%$ & $25 \%$ & $20 \%$ \\
\hline
\end{tabular}

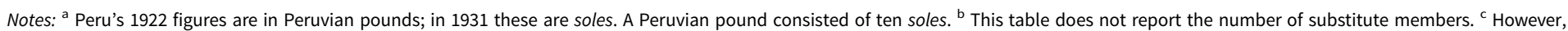
these positions could only be held by members appointed by the state. ${ }^{\mathrm{d}}$ Domestic banks are divided in different categories according to their level of capital (the benchmark volume of capital being 250,000 Peruvian pounds).

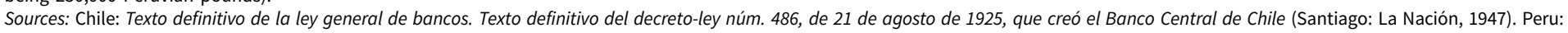

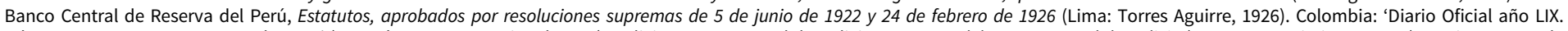
Núm. 19101 y 19102. 16. Ley 25 de 1923’ (Bogatá: Imprenta Nacional, 1923). Bolivia: Banco Central de Bolivia, Estatutos del Banco Central de Bolivia (La Paz: Renacimiento, 1930). Mexico: Banco de México, Ley, escritura y estatutos (Mexico City: Editorial Cultura, 1925). Guatemala: Molina Calderón, El Banco Central de Guatemala. 
participated in Kemmerer's missions to Chile and Mexico. ${ }^{38}$ Honduras was another country where a US money doctor, Arthur Young, was present. However, this foreign advisor did not emphasise the need to found a new central bank because the 'low volume of business' in the country would have barely justified it. ${ }^{39}$ Young instead recommended the fusion of two of the most important banks, which could operate like a central bank and be the entity responsible for the management of foreign reserves and the government's accounts.

In Peru, the Banco de Reserva del Perú (Reserve Bank of Peru) was founded in 1922 due to the influence of William Wilson Cumberland, a former student of Kemmerer's, who acted as a senior customs collector in the country. During his time in Peru, he maintained regular correspondence with Kemmerer and became a member of the new Banco de Reserva del Perú's board of directors, but resigned in 1924 as no foreign loans could be arranged. ${ }^{40}$ When Kemmerer visited Peru in January 1931, he criticised the central bank's inadequate level of capital, its lack of independence from political influence, and the predominance of one interest group (bankers) on the board of directors. ${ }^{41}$

Central banks owned and administered international reserves, and enjoyed a monopoly for issuing paper currency. The new central banks, whose ownership was a mix of both public and private entities, were intended to be independent and free from political interference, a feature that explains the long duration of the banks' defined structure and responsibilities. In each country, the government, associated banks and other private stockholders had to contribute to its capital, though levels could vary, as shown in Table 1 . The shares were divided into separate groups, each of which were assigned different voting rights. Certain kinds of shares could only be acquired either by banks, the government or the general public. In this regard, Mexico's central bank was the least independent, as the government was expected to hold at least 51 per cent of the total number of shares at any point in time.

In the countries visited by Kemmerer, the amount of capital needed was estimated on the basis of the size of the total population, its reserves and its money supply. ${ }^{42}$ In all cases, there was a minimum reserve requirement for the central bank. This was generally 50 per cent of total deposits and bills issued by the central bank, although Colombia imposed a 60 per cent level. An additional restriction concerned the total amount of loans that could be granted to the government.

\footnotetext{
${ }^{38}$ José Molina Calderón, El Banco Central de Guatemala, 1926-1946: Antecesor del Banco de Guatemala (Guatemala City: Banco de Guatemala, Seminario de Investigadores Económicos de Guatemala, 2018).

${ }^{39}$ Arthur N. Young, Reforma financiera en Honduras (Tegucigalpa: Banco Central de Honduras, 1921), p. 59. This recommendation was not implemented.

${ }^{40}$ Emily S. Rosenberg, Financial Missionaries to the World: The Politics and Culture of Dollar Diplomacy, 1900-1930 (Durham, NC: Duke University Press), p. 157.

${ }^{41}$ 'Exposición de motivos sobre el proyecto de ley para la creación del Banco Central de Reserva del Perú presentado por la Misión de Consejeros Financieros presidida por el Dr. Kemmerer', reproduced in Banco Central de Reserva del Perú, La Misión Kemmerer en el Perú (Lima: BCRP, 1998), p. 51.

${ }^{42}$ This was the case for Bolivia and Ecuador. Once the missions estimated the amount of capital needed, the next estimation concerned the amount of capital that banks and the national government could provide. The missions' reports also contained recommendations on the need for a foreign loan if financial resources were not sufficient. For Bolivia, see SGMML, EKP, box 76, folder 2. For Ecuador, see SGMML, EKP, box 154 , folder 4 .
} 
This could not exceed 30 per cent of the bank's capital, although this amount was adjusted at the onset of the Great Depression. Kemmerer had strongly criticised the high amounts of credit allocated to governments by the banks in charge of issuing currency prior to his arrival. This was the case in the Banco de la Nación Boliviana (Bank of the Bolivian Nation), which was considered to be an agency of the National Treasury. ${ }^{43}$ The newly created banks also had the capacity to pursue operations for the general public as a profit-generating activity. However, these were rarely implemented, as such operations could have introduced undesirable competition to commercial banks, whose representatives sat on the central banks' boards of directors. ${ }^{44}$

Unlike their counterparts in Mexico, Guatemala and the first central bank in Peru, representatives from the industrial sector, the agrarian sector, the government, commercial banks and labour sat on the boards of directors of Kemmerer's central banks. Having labour represented for the first time was a major achievement. In Chile, Kemmerer claimed that a labour representative could 'interpret the Bank's activities and policies to labour, who can likewise interpret to the Bank labour's attitude on questions of currency and banking policy'. He concluded: 'The chief interests of Chile's economic life are represented on the Board of Directors, but no one interest has a majority. ${ }^{35}$ Meanwhile, both domestic and foreign banks in Colombia were given the capacity to appoint representatives from agriculture and industry, a feature that would be forcefully criticised before it was abandoned in $1930 .^{46}$

As well as being expected to host government accounts and assume the role of clearing houses, Kemmerer's central banks could conduct short-term rediscount operations for limited amounts. ${ }^{47}$ Theoretically, central banks could act as lenders of last resort, granting emergency loans, stabilising the international exchange rate of the currency and managing the gold and convertible currency reserves. This was underpinned by banking legislations that set out the regulatory framework together with the conditions under which the central bank could offer support. In Ecuador, the banking legislation explicitly included a clause for the provision of support to commercial banks in an emergency.

Table 2 shows the main features of the new Latin American central banks compared to the monetary framework of other countries in the region. The first column in Table 2 shows the date when monetary law (referring to the adherence to the gold standard) was introduced. In 'Kemmerer countries', monetary laws were accompanied by new banking laws intended to regulate the banking sector and

\footnotetext{
${ }^{43}$ 'Nota personal para el doctor Casto Rojas', signed by R. Martínez Vargas, 23 May 1927, SGMML, EKP, box 76 , folder 2 .

${ }^{44}$ The press in Colombia reported on the first operations by the central bank with the general public only in Oct. 1930. See, for instance, 'El Banco de la República ha comenzado a otorgar préstamos a particulares', El Tiempo, 22 Oct. 1930.

${ }^{45}$ Draft of an article written by Edwin Kemmerer published in The Annalist, 1 Jan. 1926, SGMML, EKP, box 85 , folder 3 .

${ }^{46}$ This was explained in the 'Explanatory Memorandum for the Modifications of the Banking Law in Colombia in 1930', SGMML, EKP, box 132, folder 5.

${ }^{47}$ Central banks were thus allowed to discount short-term negotiable debt instruments which had been already discounted by commercial banks.
} 
Table 2. Central Banks vs Other Cases: Latin America in the 1920s

\begin{tabular}{|c|c|c|c|c|c|c|}
\hline Country & $\begin{array}{l}\text { Adherence to } \\
\text { gold }^{\mathrm{a}}\end{array}$ & $\begin{array}{c}\text { Exchange rate } \\
\text { management/ } \\
\text { monopoly of issue }\end{array}$ & $\begin{array}{l}\text { Regulation and } \\
\text { monitoring of banking } \\
\text { sector }\end{array}$ & $\begin{array}{l}\text { Reserve requirements } \\
\text { (percentages on } \\
\text { notes and deposits) }\end{array}$ & $\begin{array}{l}\text { Lending of last } \\
\text { resort functions }\end{array}$ & $\begin{array}{l}\text { Limit on government } \\
\text { lending (in } \\
\text { percentages of } \\
\text { bank's capital) }\end{array}$ \\
\hline \multicolumn{7}{|c|}{ Central bank foundation with presence or influence of foreign advisors } \\
\hline Peru & 1922 & Central bank & - & 50 & Yes & None \\
\hline Colombia & 23 July 1923 & Central bank & $\begin{array}{c}\text { Banking } \\
\text { Superintendency } \\
\text { Office }\end{array}$ & 60 & Yes & 30 \\
\hline Chile & $\begin{array}{l}21 \text { August } \\
1925\end{array}$ & Central bank & $\begin{array}{c}\text { Banking } \\
\text { Superintendency } \\
\text { Office }\end{array}$ & 50 & Yes & 20 \\
\hline Mexico & 1925 & Central bank & $\begin{array}{l}\text { National Banking } \\
\text { Commission }\end{array}$ & 50 & Yes & 10 \\
\hline Guatemala & 30 June 1926 & Central bank & Ministry of Finance & 40 & Yes & 40 \\
\hline Ecuador & 4 March 1927 & Central bank & $\begin{array}{l}\text { Banking Department } \\
\text { at Ministry of Finance }\end{array}$ & 50 & Yes & 20 \\
\hline Bolivia & 11 July 1928 & Central bank & $\begin{array}{c}\text { Banking } \\
\text { Superintendency } \\
\text { Office }\end{array}$ & 50 & Yes & 25 \\
\hline \multicolumn{7}{|c|}{ No central bank in the 1920 s } \\
\hline Argentina & 1927 & $\begin{array}{c}\text { Exchange } \\
\text { Stabilisation Fund }\end{array}$ & Ministry of Finance & None & $\begin{array}{l}\text { Banco de la } \\
\text { Nación / } \\
\text { Stablisation } \\
\text { Office }\end{array}$ & 20 \\
\hline
\end{tabular}


Table 2. (Continued.)

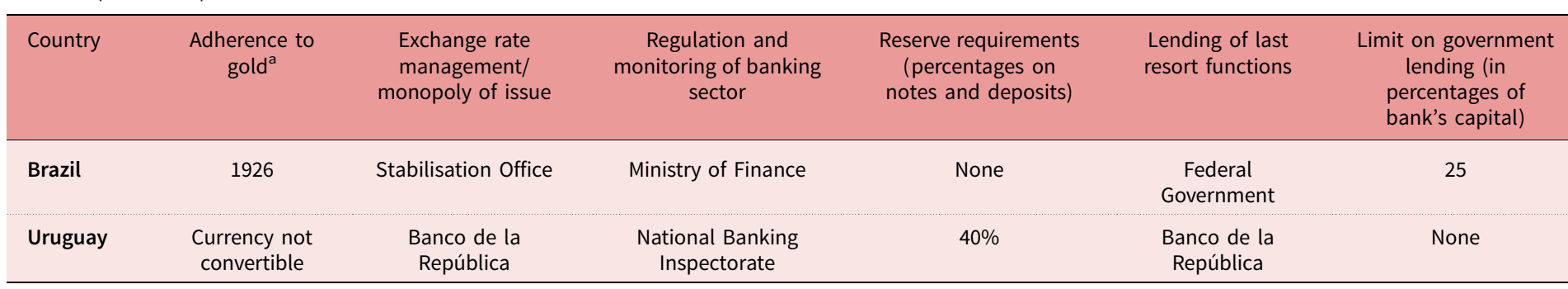

Note: ${ }^{\text {a }}$ Adherence to gold refers to the monetary law defining the convertibility of the currency.

Sources: Chile: Carrasco, Banco Central de Chile. Colombia: Ibañez Najar and Meisel Roca, 'La segunda misión Kemmerer'. Mexico: Bett, Central Banking in Mexico. Ecuador: Almeida, Kemmerer en el Ecuador. Guatemala: Molina Calderón, El Banco Central de Guatemala. Argentina: Mónica Gómez, 'El fin de la Caja de Conversión y el nacimiento del Banco Central: Argentina en la Gran Depresión, 1929-1935', in Díaz Fuentes et al., Orígenes de la globalización bancaria, pp. 381-410. Uruguay: Benjamín Nahum, Cecilia Moreira Goyetche and Lucía Rodríguez Arrillaga, Política financiera, moneda y deuda pública: Uruguay en el período de entreguerras, 1920-1939 (Montevideo: Universidad de la República Uruguay, 2014). 
promote credit according to the commercial and industrial needs of the country. ${ }^{48}$ Central banks had to meet two requirements: currency stabilisation through the adoption of a gold-exchange standard, and banking development, with currency stabilisation being the primary target. The Kemmerer missions also founded institutions such as the Banking Superintendent's Office, hosted by the Ministry of Finance, to supervise the central bank and commercial banks, with the intention of guarding the general public against bank failures. ${ }^{49}$

The banking and monetary systems introduced in Kemmerer countries meant that monetary policy would have to follow the regime's automatic mechanisms. New monetary laws stipulated the adoption of a gold-exchange standard with the establishment of gold parities. Kemmerer preferred the adoption of a goldexchange standard: it had the same automatic mechanisms as the gold standard, ${ }^{50}$ but it discouraged the hoarding of metallic reserves. The gold-exchange standard was thus seen to be particularly well-suited to economies that 'did not have enough material resources to guarantee gold circulation and reserves or could not guarantee gold bullion convertibility' ${ }^{51}$

\section{Credit Provision}

One of the main motivations for the introduction of banking reforms in the 1920s was the unsatisfied demand for long-term credit to the private sector. However, given the generalised adoption of the gold standard, deflationary policies were followed during the first years of the new central banks. As a result, these new institutions were unable to meet the general need for capital sought by different productive sectors.

In principle, the rise in credit was supposed to operate through the increased availability of capital that could be lent at reduced interest rates. This could be undertaken through increased competition among commercial banks. In Bolivia, Kemmerer attempted to lower the high degree of concentration in the banking sector. The banking laws that he recommended aimed at facilitating the establishment of new banks. ${ }^{52}$ Furthermore, all Kemmerer's central banks, including Peru's in 1931, established branches with the ability to deal directly with the public.

The disappointment that followed the establishment of central banks developed rapidly in most cases. Several criticisms were raised in favour of a more proactive policy that could facilitate credit to the economy, something that central banks had refused to do prior to the 1930s. Drake reports that in Colombia,

\footnotetext{
${ }^{48}$ For Ecuador, see Almeida, Kemmerer en el Ecuador.

${ }^{49}$ See, for instance, the case of Bolivia: 'Project of a General Banking Law', 26 June 1927, SGMML, EKP, box 79, folder 2. 'Proyecto de ley para la creación del Banco Central del Ecuador', Comisión de Consejeros Financieros presidida por el señor Edwin Walter Kemmerer, SGMML, EKP, box 154, folder 4.

${ }^{50}$ Under a gold-standard regime, a country was prevented from running large and persistent deficits or surpluses. A country running a deficit would see its currency depreciate to the gold-export point.

${ }^{51}$ Rebeca Gomez Betancourt, 'Edwin Walter Kemmerer: Money Theorist and Money Doctor', PhD diss., Université Paris 1 Panthéon-Sorbonne, 2008, p. 231.

${ }^{52}$ Report in Support of a Project of a General Banking Law as Submitted to the President of the Republic and the Minister of Finance in June 1927 by the Commission of Financial Advisers', SGMML, EKP, box 79, folder 5 .
} 
agriculturalists, who had initially been in favour of a bank that specialised in providing credit perceived as necessary to support their sector, felt excluded from the credit policy of the newly established central bank, while Chilean agriculturalists also complained about credit shortages. ${ }^{53}$ In Ecuador, Rebeca Almeida reports that a fall in price of the main exports triggered a deficit in the current account after 1927, prompting the central bank to reduce the monetary reserves, although it maintained a level of reserve that largely exceeded the minimum required. Hence, even if discount rates decreased between 1927 and 1929, the central bank forcefully curbed its credit policy. The central bank reacted to criticism that cited the mismatch created by Kemmerer's banking laws and the real necessities of the economy by referring to the fact that short-term credit had to be provided by commercial banks rather than by the central bank. ${ }^{54}$

In certain cases, governments mounted a response to the demand for credit increases through the establishment and promotion of both public and specialised commercial banks. After the central bank was founded in Guatemala, a new bank called the Banco de Crédito Hipotecario Nacional (National Mortgage Credit Bank) was established in 1929, whose main priority was to grant credit to the agricultural sector. $^{55}$ Furthermore, and contrary to 'Kemmerer banks', the central bank included an agricultural mortgage department which was granted 25 per cent of the bank's paid-in capital. ${ }^{56}$ In Mexico, a similar bank called the Banco Nacional de Crédito Agrícola (National Agricultural Credit Bank) was established in 1926, one year after the foundation of the central bank. ${ }^{57}$ The same motivation prompted the government to create the Caja de Crédito Hipotecario (Mortgage Credit Bank) and the Caja de Crédito Agrario (Agricultural Credit Bank) in Chile. ${ }^{58}$ As we shall see, complaints about the shortage of credit became even more acute when the effects of the Great Depression deepened throughout the region.

There were also increased demands for credit from the industrial sector. In Peru, the financial sector had concentrated on credit for consumption and imports since the late nineteenth century, and this remained a primary focus until the $1920 \mathrm{~s}^{59}$ Juan Franco Lobo Collantes argues that the first initiatives to provide financial support to Peru's industrial sector date from March 1929, following discussions in Parliament. ${ }^{60}$ According to this author, Kemmerer's banking laws affected long-

\footnotetext{
${ }^{53}$ See Drake, Money Doctors, Foreign Debts, and Economic Reforms, p. 43; Fabio Sánchez-Torres and Juan Guillermo Bedoya-Ospina, 'La danza de los millones, 1923-1931', in José Darío Uribe (ed.), Historia del Banco de la República, 1923-2015, (Bogotá: Banco de la República, 2017), pp. 25-84.

${ }^{54}$ Almeida, Kemmerer en el Ecuador, p. 136.

${ }^{55}$ José Molina Calderón, Guatemala: Un siglo y seis lustros de banca, bancos y banqueros (1877-2007) (Guatemala City: Banco Industrial de la Ciudad de Guatemala, 2007), p. 138.

${ }^{56}$ Statutes of the Central Bank of Guatemala, published in José Molina Calderón, El Banco Central de Guatemala, 1926-1946, p. 58.

${ }^{57}$ Alberto R. Pani, Los orígenes de la política crediticia: Con la réplica y las contrarréplicas suscitadas (Mexico City: Atlante, 1951), p. 57.

${ }^{58}$ Drake, Money Doctors, Foreign Debts, and Economic Reforms, p. 113.

${ }^{59}$ Martín Monsalve Zanatti, 'Industria y mercado interno, 1821-1930', in Carlos Contreras (ed.), Compendio de historia económica del Perú, vol. 4: Economía de la primera centuria independiente (Lima: IEP, BCRP, 2011), pp. 239-301.

${ }^{60}$ Juan Franco Lobo Collantes, 'La construcción de las políticas industriales en el Perú, 1930-1939', PhD diss., Universidad Nacional Mayor de San Marcos, 2013.
} 
term credit, as commercial banks had prioritised short-term transactions. The lack of credit for this sector, along with that of agriculture, worsened further during the crisis years with the liquidation of the Banco del Perú y Londres (Bank of Peru and London) severely affecting the agro-exporting sector. In response to the pressing needs of the agrarian sector, the first state-sponsored 'development bank', Banco Agrícola (Agricultural Bank), was created in August 1931 with funds from the central bank's reserve. ${ }^{61}$ The Banco Industrial (Industrial Bank) was created one year later.

\section{Countries with No Central Banks}

In Argentina, Brazil and Uruguay, countries without a proper central bank, the leading commercial banks were charged with the provision of rediscount operations to commercial banks, the management of public finances and servicing debt. In all cases, one common target was to maintain a fixed exchange standard, which largely imposed the same kind of restrictions on monetary policy. However, functions such as monetary issuing, banking regulation and even monetary policy were shared with other entities such as the Ministry of Finance (Uruguay) or exchange stabilisation offices (Argentina and Brazil). In Argentina, this conversion office was established in 1899 and acted like a currency board, issuing paper money in exchange for specie at a specified fixed nominal value. A similar entity was created in Brazil in 1906, though it operated within the Banco do Brasil. ${ }^{62}$ In Uruguay, the Banco de la República Oriental del Uruguay (Bank of the Eastern Republic of Uruguay, BROU) held the monopoly on issuing currency, although the quantity of money in circulation and the supervision of commercial banks were controlled by the government. ${ }^{63}$

These countries shared the same problems related to the scarcity of credit to the private sector. In Uruguay during the 1920s, there was persistent criticism of the government and the BROU for not providing sufficient credit to the rural and industrial sectors. ${ }^{64}$ The policy of restricting credit demonstrated that the government's first priority was to bring the country within the gold-exchange standard. In Argentina, Andrés Martín Regalsky and Mariano Iglesias argue that the Banco de la Nación had pursued a counter-cyclical credit policy, in contrast to commercial banks. ${ }^{65}$ Even though the level of deposits had been expanding in the late 1920s, the Banco de la Nación, along with other banks, initially decided to increase its levels of reserves as the balance of payments was favourable. The

\footnotetext{
${ }^{61}$ Alfonso W. Quiroz, Domestic and Foreign Finance in Modern Peru, 1850-1950: Financing Visions of Development (Basingstoke: Macmillan, 1993), p. 180.

${ }^{62}$ Fritsch, External Constraints; Gail D. Triner, 'The Formation of Modern Brazilian Banking, 1906-1930: Opportunities and Constraints Presented by the Public and Private Sectors', Journal of Latin American Studies, 28: 1 (1996), pp. 49-74.

${ }^{63}$ Carolina Román, 'Política monetaria y oferta de dinero en Uruguay (1931-1959): Nuevos contextos y nuevos instrumentos', IECON Working Papers, 2010.

${ }^{64}$ Raúl Jacob, Uruguay, 1929-1938: Depresión ganadera y desarrollo fabril (Montevideo: Fundación de Cultura Universitaria, 1981).

${ }^{65}$ Andrés Martín Regalsky and Mariano Iglesias, 'Entre la inestabilidad y el orden: El sistema bancario argentino entre 1890 y 1930', in Díaz Fuentes et al., Orígenes de la globalización bancaria, p.135.
} 
increase of deposits and reserves ran parallel between 1928 and $1929 .{ }^{66}$ In Brazil, the expansion of credit was also linked to the balance of payments - largely dependent upon the price of coffee - and the capacity of the Coffee Institute to stabilise it. As the balance of payments remained positive, the Banco do Brasil had expanded its lending operations, but the sudden deterioration of the country's external position in 1928 triggered a shift in this policy. This sharp reversal severely affected the private sector, causing a liquidity crunch that required the Banco do Brasil to intervene. ${ }^{67}$

\section{The Impact of the Great Depression}

The economic impact of the Great Depression was uneven in Latin America. Table 3 shows real GDP figures for a sample of countries between 1929 and 1933. The decline in economic activity seems to have been more acute in Chile and Peru, while Ecuador experienced a mild slowdown in its level of economic growth. ${ }^{68}$ During that period, economic performance was strongly dependent upon the behaviour of the external sector. Table 3 shows that all countries experienced a slump in the total value of exports, though here again there were important differences among the countries analysed.

It is of interest that the decline in exports was not reflected in a deterioration of trade deficits. This is related to commercial policies that aimed to restrict imports as well as contractionary monetary policies. As Table 3 shows, the fall in gold reserves was a prominent feature, suggesting that capital outflows were a major problem during these critical years. As central banks and monetary authorities followed the rules imposed by the gold standard, the monetary base declined accordingly.

The need to defend the convertibility and value of Latin American currencies demanded that the monetary authorities and central banks react with the tools at their disposal. Carlos F. Díaz-Alejandro claims that in Central America and the Caribbean, countries maintained their peg to the US dollar throughout the 1930s, with practically no exchange controls. ${ }^{69}$ However, in the case of Haiti, Guy Pierre argues that this had a strong negative impact on credit and on economic performance. ${ }^{70} \mathrm{He}$ reports that US authorities impeded the national bank, whose head office had been established in the United States, to engage in counter-cyclical policies. In countries with central banks, all raised their discount rates to preserve their reserves and currency convertibility (see Figure 1), but this reaction was

\footnotetext{
${ }^{66}$ In 1934, Niemeyer criticised this behaviour as it interfered with the operation of the gold standard. Otto Niemeyer, 'Informe de Sir Otto Niemeyer', Revista Económica del BNA, 1934.

${ }^{67}$ Fritsch, External Constraints, p. 140.

${ }^{68}$ See Rosemary Thorp, Latin America in the 1930s: The Role of the Periphery in the World Crisis (London: Macmillan, 1984), p. 10. In the introduction, Thorp argues that mining exports were particularly hit by the crisis. Therefore, countries relying more on this sector were particularly affected (Bolivia, Chile, Mexico).

${ }^{69}$ Carlos F. Díaz-Alejandro, 'Stories of the 1930s for the 1980s', in Pedro Aspe Armella, Rudiger Dornbusch and Maurice Obstfeld, Financial Policies and the World Capital Market: The Problem of Latin American Countries (Chicago, IL: University of Chicago Press, 1983), pp. 5-40.

${ }^{70}$ Guy Pierre, La crise de 1929 et le développement du capitalisme en Haiti: Une perspective de longue durée et une conjoncture perdue (Montreal: CIDIHCA, 2015).
} 
Table 3. Current Account and Reserve Losses in Latin America

\begin{tabular}{|c|c|c|c|c|c|c|c|c|c|c|}
\hline Year & ARG & $\mathrm{BOL}$ & BRA & $\mathrm{CHI}$ & $\mathrm{COL}$ & ECU & GUA & MEX & PER & URU \\
\hline \multicolumn{11}{|c|}{ Real GDP $(1929=100)$} \\
\hline 1929 & 100.0 & - & 100.0 & 100.0 & 100.0 & 100.0 & 100.0 & 100.0 & 100.0 & 100.0 \\
\hline 1931 & 89.2 & - & 91.9 & 66.2 & 97.6 & 104.5 & 97.4 & 96.9 & 81.4 & 94.0 \\
\hline 1932 & 86.3 & - & 95.1 & 55.9 & 104.0 & 105.1 & 85.1 & 82.3 & 78.3 & 87.3 \\
\hline \multicolumn{11}{|c|}{ Total exports $(1929=100)$} \\
\hline 1929 & 100.0 & 100.0 & 100.0 & 100.0 & 100.0 & 100.0 & 100.0 & 100.0 & 100.0 & 100.0 \\
\hline 1930 & 98.7 & 70.3 & 158.3 & 58.1 & 89.0 & 94.1 & 96.0 & 129.0 & 65.7 & 94.6 \\
\hline 1931 & 89.7 & 45.9 & 92.9 & 35.8 & 111.8 & 64.7 & 60.0 & 101.2 & 41.0 & 46.7 \\
\hline 1932 & 62.7 & 37.8 & 67.1 & 12.2 & 77.2 & 47.1 & 44.0 & 57.6 & 28.4 & 29.3 \\
\hline 1930 & -1.8 & 38.5 & 39.5 & -4.9 & 39.8 & 18.8 & 29.2 & 52.9 & 42.0 & 10.3 \\
\hline 1931 & 37.0 & 52.9 & 43.3 & 14.0 & 69.0 & 18.2 & 13.3 & 68.2 & 47.3 & -14.0 \\
\hline 1932 & 43.4 & 57.1 & 41.7 & 23.5 & 66.3 & 25.0 & 36.4 & 61.2 & 57.9 & 3.7 \\
\hline 1933 & 30.7 & 50.0 & 15.6 & 46.0 & 36.6 & 28.6 & 11.1 & 42.1 & 59.2 & 3.1 \\
\hline
\end{tabular}


Table 3. (Continued.)

\begin{tabular}{|c|c|c|c|c|c|c|c|c|c|c|}
\hline Year & ARG & BOL & BRA & $\mathrm{CHI}$ & $\mathrm{COL}$ & ECU & GUA & MEX & PER & URU \\
\hline 1929 & 85.71 & 225.10 & 100.20 & 83.09 & 58.51 & 92.37 & 75.00 & 161.61 & 90.01 & 88.93 \\
\hline 1931 & 53.27 & 62.35 & 13.83 & 36.25 & 21.21 & 41.05 & 56.25 & 40.28 & 62.64 & 67.06 \\
\hline 1932 & 52.45 & 67.61 & 47.37 & 28.62 & 26.63 & 45.79 & 50.00 & 99.05 & 41.83 & 65.74 \\
\hline
\end{tabular}

Sources: GDP and international trade figures are from Montevideo-Oxford Latin American Economic History Database (MOxLAD). Data on reserves are from League of Nations, Statistical Yearbook, various issues. 


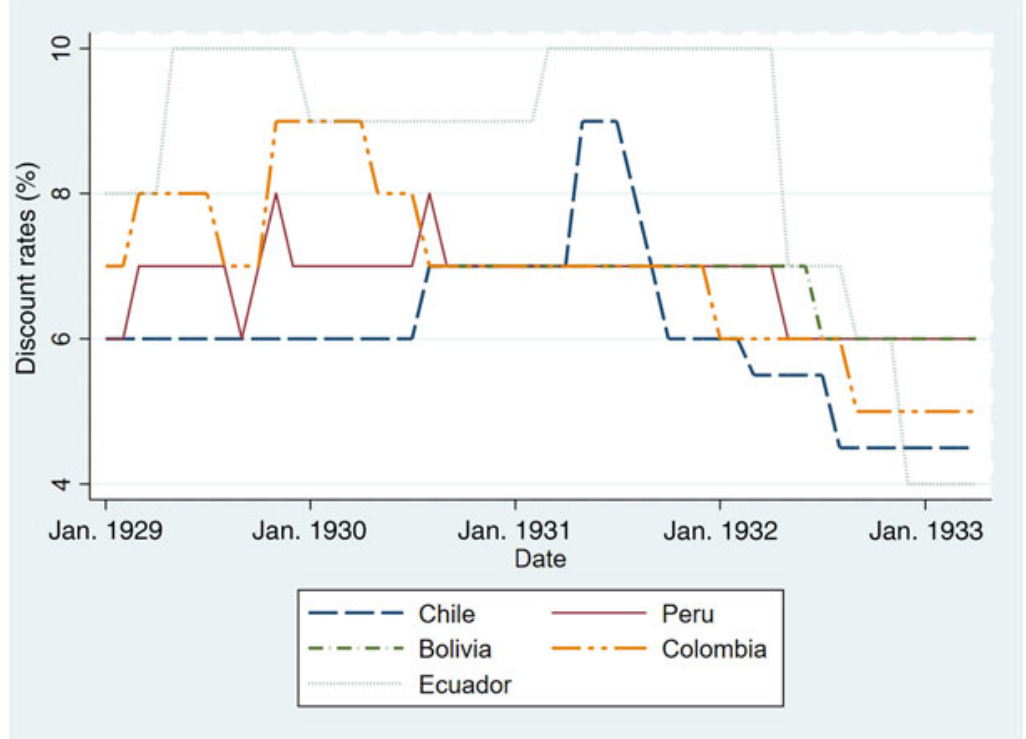

Figure 1. Discount Rates in Latin America

Source: Federal Reserve Bulletin, various issues. Chile's figures are those corresponding to 'Rediscount Rates to Associated Banks' as published in the central bank's annual reports.

neither necessarily favourable to economic recovery nor to the needs of the banking sector.

The literature has not entirely assessed the impact that this contractionary policy had on banks. Díaz-Alejandro has emphasised that no widespread banking failures were reported in Latin America during the 1930s. ${ }^{71}$ Ben S. Bernanke and Harold James include Argentina (in April 1931) and Mexico (in July 1931) as the only interwar banking crises that took place in Latin America, but such a perspective is probably misleading. ${ }^{72}$ The banking sector in Latin America was persistently under financial distress, and banking failures and sporadic banking runs were reported in various countries after 1930. Figure 2 shows the generalised fall in deposits in all of the countries analysed.

In Mexico, the central bank's charter provided several mechanisms through which the bank was allowed to support associated banks. ${ }^{73}$ However, even if the central bank was legally prevented from supporting non-associated banks (which were the vast majority), Virgil Marion Bett argues that it helped several banks to weather the storm. ${ }^{74}$ The minutes of the board of directors show that during 1931 the central bank conceded several loans and rediscount operations to

\footnotetext{
${ }^{71}$ Díaz-Alejandro, 'Stories of the 1930s for the 1980s', p. 18.

${ }^{72}$ Ben S. Bernanke and Harold James, 'The Gold Standard, Deflation, and Financial Crisis in the Great Depression: An International Comparison', in Robert Glenn Hubbard (ed.), Financial Markets and Financial Crises (Chicago, IL: University of Chicago Press, 1991), pp. 33-68.

${ }^{73}$ Eduardo Turrent Díaz, Historia del Banco de México (Mexico City: El Banco de México, 1982).

${ }^{74}$ Virgil Marion Bett, Central Banking in Mexico: Monetary Policies and Financial Crises, 1864-1940 (Ann Arbor, MI: University of Michigan Press, 1957), p. 55.
} 


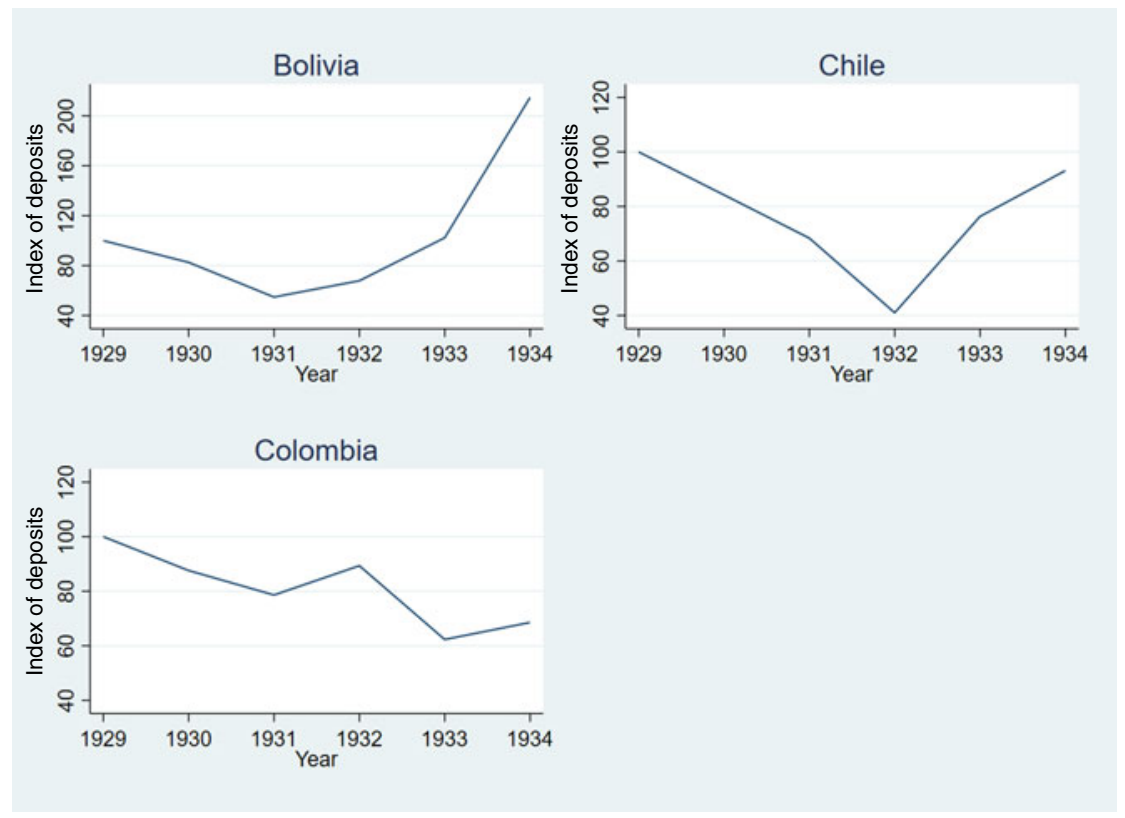

Figure 2. Fall in Deposits: Commercial Banks

2.1. 'Kemmerer' countries

Notes: Deposits are reported in local currency. They were converted to dollars using the exchange rates published in the source below. Indexes are estimated utilising $1929=100$.

Source: League of Nations Statistical Yearbook for 1937.

associated and non-associated banks. ${ }^{75}$ They also show, nevertheless, that the central bank, given its own fragile position, was extremely careful about the credit granted to the banks in distress. ${ }^{76}$ In the case of the Banco de Sonora (Sonora Bank), an important bank in the north of the country and whose problems were directly linked with the banking crises in the United States, the central bank feared the possibility of a systemic banking failure in the region, prompting it to support the bank. $^{77}$

In Peru, a first banking crisis hit after the military coup in August 1930, when the Banco del Perú y Londres faced a massive run on its deposits in October $19300^{78}$ The bank was in a delicate situation as it had a close relationship with the deposed government, and public suspicion on the misuse of funds triggered the panic. ${ }^{79}$ While this bank was the most important in the country, the whole banking system

\footnotetext{
${ }^{75}$ These operations include loans to Banco Nacional de México in Aug. 1931 and Banco Refaccionario de Occidente in Sept. (both associated banks) and Banco de Nuevo León (not associated). See Actas del Consejo 365, 368, 370 and 378, 1931, Archivos de Banco de México (henceforth ABM).

${ }^{76}$ This was the case of a credit requested by the Banco Refaccionario de Occidente, whose financial assets to be used as guarantee did not completely convince the board of directors, and had thus to modify the amount of credit to be granted. See Acta del Consejo 368, 1931, ABM.

${ }^{77}$ Acta del Consejo 370, 1931, ABM.

${ }^{78}$ Quiroz, Domestic and Foreign Finance, p. 82.

${ }^{79}$ Gonzalo Portocarrero, 'Del monetarismo al keynesianismo: La política económica durante la crisis del 30', Economía, 4 : 7 (1981), pp. 65-98.
} 

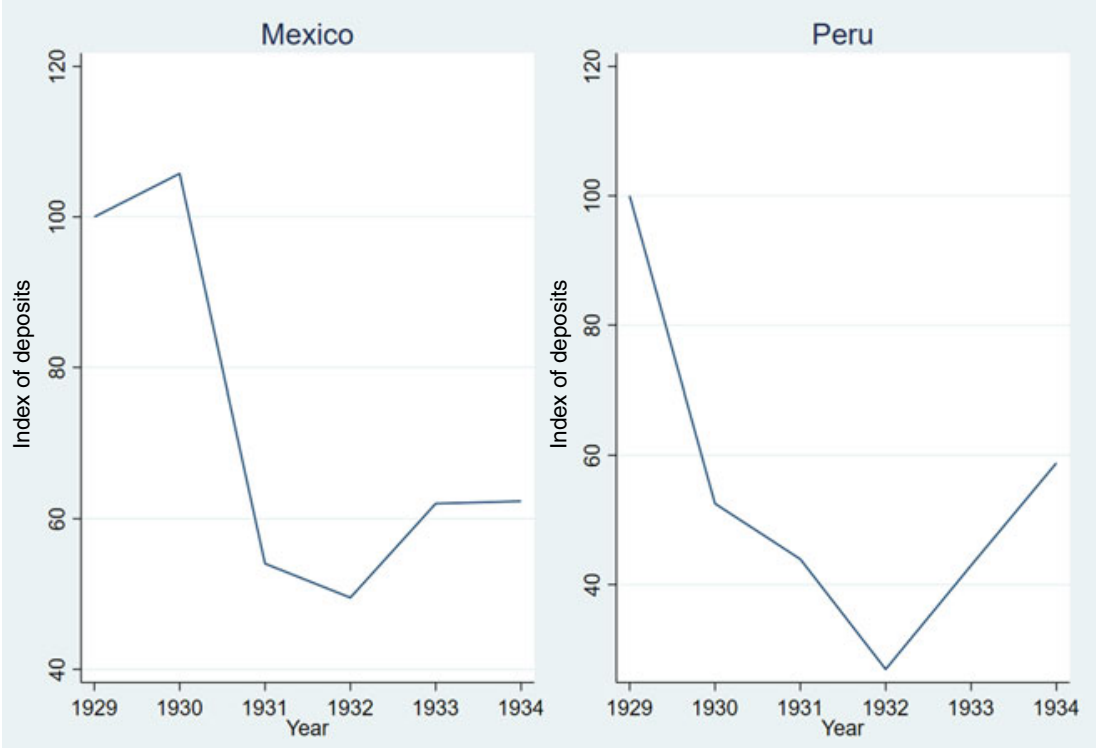

Figure 2. Continued

2.2. Countries with Central Banks
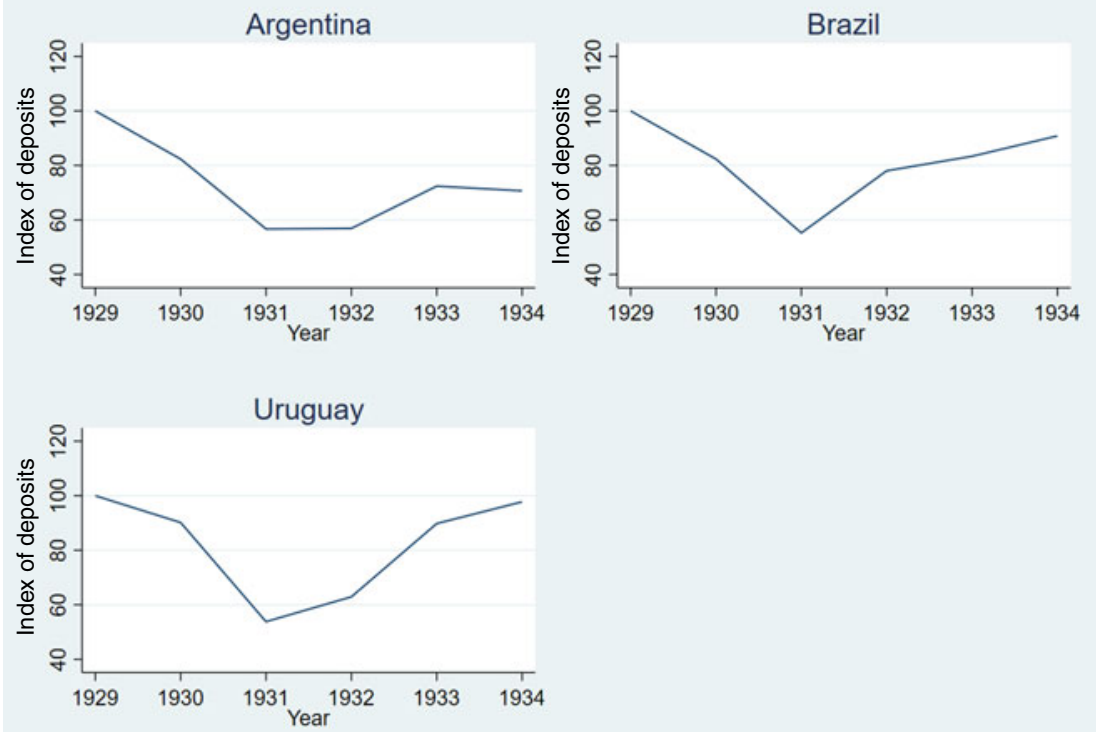

Figure 2. Continued

2.3. Countries without Central Banks 
was particularly fragile as it operated without proper regulation. The Banco de Reserva del Perús annual report for that year does not provide further details about the support provided to Banco del Perú y Londres. The same report for the previous year shows that the bank absorbed around one-fifth to one-quarter of total loans and discount operations within the banking sector. ${ }^{80}$

In Chile, the minutes of the central bank's directorate show that gold outflows had prompted it to increase its discount rates during the first months of 1931 and had also raised concerns regarding the effects of deposit withdrawals from commercial banks. ${ }^{81}$ The central bank had not only raised interest rates, but also rationed the total amount of rediscounts despite the negative effect this had on banks. The directorate perceived that the risks to the country's banking and monetary situation were the deterioration of the balance of payments and the fiscal position of the government; it also regretted that the bank had no tool other than the rediscount rate to forestall the decline in gold reserves. ${ }^{82}$

\section{Policy Shifts and External Constraints}

The initial reaction of governments and central banks was to avoid the fiscal deficits that accompanied the economic slump and to follow the rules of the gold standard. While the crisis was at first considered to be transitory, alternative solutions were sought when exports continued falling, disequilibria in public finances became acute and access to foreign capital markets proved complicated. ${ }^{83}$ One of the solutions involved a renewed round of visits from money doctors, which saw Kemmerer in Colombia in 1930 and in Peru during the first months of 1931.

The Conference of South American Central Banks in Lima in December 1931 served to raise the mood. It was initially convened by Bolivia's central bank in the aftermath of the British sterling pound's departure from the gold standard. The participants of the conference included representatives from Colombia, Chile, Peru and the United States. Five main issues were discussed: the diminution of gold reserves, the consequent reduction of the circulating medium, the forced restriction of credit, debt defaults leading to capital outflows, and effective remedies to mitigate the effects of the crisis.

The memorandum sent by Bolivia's central bank to the conference participants stressed the problem of the restriction of credit. The document raised concerns regarding the rules of the gold-standard regime, particularly when there was an unfavourable position in the balance of payments, as this could trigger excessive pressures on the monetary supply, thereby causing violent deflation and generating economic and social turmoil. ${ }^{84}$ Among the solutions proposed in the memorandum, one related to assistance from the Federal Reserve Board to provide credit

\footnotetext{
${ }^{80}$ Banco de Reserva del Perú, Memoria del Banco Central de Reserva del Perú (Lima: BCRP, 1929 and 1930).

${ }^{81}$ Actas Sesiones del Ex Directorio, Acta 234, 7 May 1931, Chilean Central Bank Digital Repository (hereafter CCBDR).

${ }^{82}$ Actas Sesiones del Ex Directorio, Acta 235, 11 May 1931, CCBDR.

${ }^{83}$ Memorandum, entitled 'Latin American Borrowing', 3 March 1930, BoEA, file OV102/1.

${ }^{84} \mathrm{~A}$ translated version of the 'Memorandum on the Subjects To Be Submitted to the Conference of the Central Banks', 18 Nov. 1931, can be found in BoEA, file OV188/1.
} 
'that it would grant us and on conditions adjustable to the existing circumstances' ${ }^{85}$ Other solutions directly involved the monetary regime, such as those having the 'object of giving greater elasticity to paper money'. ${ }^{86}$ During the conference, the main topic discussed was the preservation of the gold standard and its implications for central banks' operations during the crisis. These included the central banks' capacity to face balance of payments imbalances and the need by governments to avert fiscal deficits. The discussions also referred to the criticisms raised in the central banks' respective countries that restrictive monetary policies aggravated the Depression. ${ }^{87}$ The final communique from the conference showed the willingness of Kemmerer central banks to cooperate and remain on the gold standard. ${ }^{88}$ However, as a British observer reported to the Foreign Office, what the [South] American 'Bankers really wanted were further loans from New York or $[\ldots]$ to persuade the Federal Reserve Bank to extend credit over longer periods'.

The onset of the Great Depression coincided with turbulent political times in Chile, Colombia and Peru. As reported by the UK's Overseas and Foreign Department, the severe orthodox policy pursued by South American central banks and the fiscal needs of the governments eventually altered central banks' charters. ${ }^{90}$ The effects of the economic crisis had prompted governments to introduce agricultural and public works programmes. Furthermore, three of the five Kemmerer countries were engaged in wars. Therefore, central banks saw their statutes being modified during 1931 to meet the demands for credit from both the government and the private sector. In 1933, a memorandum at the Bank of England summarised the main reforms in some of these countries. The document showed how Chile's central bank was permitted to purchase a broader set of financial assets to allow it to purchase bonds from the government. The bank also raised its legal limit of advances to the government from the previous 20 per cent to 80 per cent of its capital and reserves. The minimum gold reserve was reduced from 50 per cent to 35 per cent. The memorandum, published in January 1933, reproduced the monthly report on credit and business conditions of the central bank, in which it lamented that the central bank had been converted into a bank of issue under Government control'. The memorandum also reported that similar measures had been introduced in Colombia and Ecuador. ${ }^{91}$

The initial and orthodox reactions of Latin American governments did not mean that they were unaware of the problems that persisted in their economies. In

\footnotetext{
${ }^{85}$ Ibid.

${ }^{86}$ Ibid.

${ }^{87}$ Unofficial English Translation of the Resolutions Adopted by a Conference of South American Central Banks. Lima, Peru, December 1 to 12, 1931' sent by Allan Sproul, Assistant Deputy Governor, Federal Reserve, to J. A. C. Osborne, Bank of England, BoEA, file OV188/1.

${ }^{88}$ The closing speech given by Peru's central bank president, Olaechea, reproduced in Lima's newspaper El Comercio, referred largely to the problem of internal credit. 'Sesión de clausura de la Conferencia de Bancos Centrales', El Comercio, 13 Dec. 1931. An editorial in the same newspaper insisted on the need for long-term credit for the recovery of industry (El Comercio, Editorial, 14 Dec. 1931).

${ }^{89}$ Letter from C. H. Bentinck to Sir John Simon, 17 Dec. 1931. BoEA, file OV188/1.

${ }^{90}$ 'Central Banking in South America', memorandum by the Overseas and Foreign Department, 30 Nov. 1934, BoEA, file OV188/1.

${ }^{91 ‘}$ 'Central Banks in Latin America', memorandum, 25 May 1933, BoEA, file OV188/1.
} 
Colombia, the demands from different sectors of the economy favoured an expansionary monetary policy. ${ }^{92}$ In the case of Mexico, Alberto Pani, who had acted as secretary of finance since 1923, promoted pension and banking reforms designed to increase domestic savings and credit. ${ }^{93}$ In fact, as stressed by Rosemary Thorp, the need for state intervention, particularly regarding banking development, had been present long before the Great Depression, although the event permitted, rather than created, the new economic paradigm that would emerge during the 1930s. ${ }^{94}$ In Peru, Alfonso W. Quiroz reports that Kemmerer's mission produced a set of documents recommending a new banking regulation, central bank reorganisation, a return to the gold standard, and tax reform. ${ }^{95}$ Even then, Quiroz argues that most of these measures were either not implemented or were modified in a direction contrary to Kemmerer's recommendations, thereby expanding central bank loans to governments and allowing the agrarian export sector to strongly influence the country's financial policy.

Figure 3 shows the dates on which a sample of Latin American countries left the gold standard, and the ratio of gold reserves to the issue of banknotes when this decision was implemented. Figure 3 confirms that the low level of reserves was not necessarily the main variable explaining the decision to abandon the monetary regime. As Kemmerer himself argued: 'A number of these countries which went off the gold standard had large amounts of gold. ${ }^{96}$ Interestingly, the countries without a central bank were those that left first, even though the level of reserves was still relatively high. On the contrary, countries under 'money doctoring' were those that left last. Pablo Gerchunoff and José Luis Machinea argue that in Argentina, the political weakness of President Yrigoyen prompted him to react and prevent recessive pressures on the economy, despite the risks that such a decision might have entailed. ${ }^{97}$ Argentina and Brazil were among the first countries to offer discount facilities to their banking sectors in unorthodox ways. The reaction in Brazil to the Great Depression included the provision, in 1930, of rediscounting facilities through the Carteira de Redesconto (Rediscount Portfolio). This policy was complemented in 1932 by making available the reserves of the Caixa de Mobilização Bancária (Banking Mobilisation Office). In both countries, conversion offices facilitated discount operations and each established an Instituto Movilizador de Inversiones Bancarias (Investment Banking Mobilisation Institute). ${ }^{98}$

\footnotetext{
${ }^{92}$ Jorge Enrique Ibañez Najar and Adolfo Meisel Roca, 'La segunda misión Kemmerer', in Banco de la República (Colombia), El Banco de la República: Antecedentes, evolución y estructura (Bogotá: Banco de la República, 1990), p. 782.

${ }^{93}$ Aurora Gómez-Galvarriato, 'La política económica del nuevo régimen: Alberto J. Pani, 1923-1927, 1931-1933', in Leonor Ludlow, Los secretarios de hacienda y sus proyectos (1821-1933), vol. 2 (Mexico City: UNAM, 2003), pp. 381-412.

${ }^{94}$ Thorp, Latin America in the 1930s, p. 10.

${ }^{95}$ Quiroz, Domestic and Foreign Finance, p. 178. This kind of advice was not different from previous missions to other South American countries.

${ }^{96}$ Statement of Edwin Walter Kemmerer, 'Banking Act of 1935. Hearings before a Subcommittee of the Committee on Banking and Currency, United States Senate, April 19 to May 13, 14 to May 22, 1935' (Washington, DC: US Government Printing Office, 1935), p. 330. Exchange controls began to be introduced in different countries in 1931.

${ }^{97}$ Pablo Gerchunoff and José Luis Machinea, 'Circulando en el laberinto: La economía política de la salida del patrón oro en la Argentina (1929-1933)', Revista CEPAL, 117 (Dec. 2015), pp. 109-26.

${ }^{98}$ Villela, 'Las funciones de banca central', p. 442.
} 


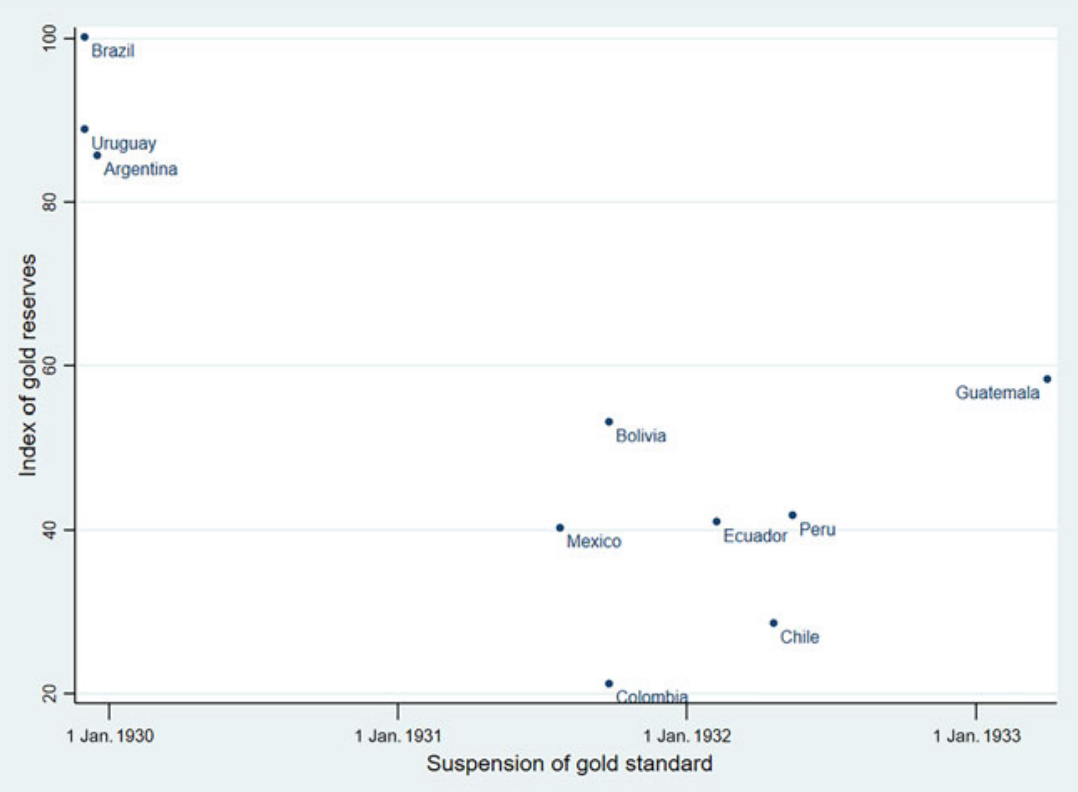

Figure 3. Gold Reserves to Note Issue Ratio and Abandonment of the Gold Standard Note: Index of gold reserves to note issues, base year is $1928=100$.

Sources: League of Nations Statistical Yearbook for 1934 and 1937. Dates for countries leaving gold standard: Federal Reserve Monthly Bulletin, various issues.

\section{Central Banks in the 1930s}

While the first countries to seek external support had been the 'Kemmerer countries', they were not alone. Within the government of Mexico, the promoters of the gold standard had been in contact with the foreign monetary advisor although no formal invitation was sent. ${ }^{99}$ In Uruguay, H. A. Lawrence (from the bank Glyn, Mills and Company) provided policy recommendations to face the economic crisis, while basically exhorting the government to adhere to the gold standard. ${ }^{100}$ An unsigned report at the Bank of England, dated 25 October 1935, justified Uruguay's decision not to establish a central bank due to the president's unwillingness to relinquish control of the currency. ${ }^{101}$ British missions were sent to Brazil, Argentina and El Salvador, and provided the structure and design of central banks. While the government in Brazil did not implement the recommendations of the mission led by Niemeyer, it is interesting to compare the design of these banks with those conceived by Kemmerer and also with the one being established in Venezuela, whose government designed a new central bank after considering previous experiences in the Americas.

\footnotetext{
${ }^{99}$ This was the case of Montes de Oca. Minister of Finance Luis Manuel Anaya Merchant, 'México no gana el oro que gasta: Eso es la crisis. Polémicas sobre las reformas monetarias de 1931 y 1932', América Latina en la Historia Económica, 20: 3 (2013), pp. 170-209.

${ }^{100} \mathrm{Jacob}$, Uruguay, p. 317.

${ }^{101 ' B a n k}$ of England Missions to South America', 25 Oct. 1935, BoEA, file OV188/2.
} 
In an attempt to maintain British trading connections and financial influence, the Bank of England had constantly monitored central banks in Kemmerer countries. ${ }^{102}$ In an unsigned report at the Bank of England, dated 25 May 1933, the author signalled that these institutions were not suitable for the conditions in Latin American countries. In particular, the document argued that the financial reserves of these countries were completely dependent upon the export trade of a few primary products. Exchange volatility was thus part of the economy and not necessarily a source of major concern. The report also referred to the insistence upon balanced national budgets, which were rarely achieved, and the consequent problems of public debt. Finally, the report addressed the problem of political interference in central banks with governments turning to central banks for financing due to the crisis. The report noted that the original laws had foreseen that governments would hold bank shares and nominative powers for a certain number of members of the boards. ${ }^{103}$

Niemeyer did not agree with the main claims of the document. He warned that the advice given by Kemmerer did not 'provide sufficiently for practical dangers or local administrative conditions' while admitting that 'his results cannot be fairly estimated on the present crisis'. ${ }^{104}$ Niemeyer also criticised the fact that South American governments held shares in Kemmerer central banks, something with which he strongly disagreed. It would appear that Niemeyer's position was not so different from Kemmerer's. Some years before, Kemmerer had claimed that the principal objective of a central bank - which he defined as a quasi-public institution - was to protect the standard of value and to conserve the financial interests of the entire public. ${ }^{105}$ While he did not normally advocate that governments should invest in the stock of a central bank, he insisted that sometimes an initial investment was necessary for the creation of one that was strong. ${ }^{106}$ Regarding directors, the government, 'representing the broad public interest, should have a substantial representation, regardless of whether it owns stock in the [central] Bank or not'. ${ }^{107}$

This difference can be observed in Table 4. Other differences include the nomination of members of the board of directors (more comprehensive in Kemmerer's banks) and the relative amount of capital. Niemeyer favoured low levels of capital (contrary to Kemmerer) as he believed that 'large capital necessitates large profits in order to meet dividend charges', thereby distorting the activities of the bank. ${ }^{108} \mathrm{He}$ did however echo Kemmerer in his emphasis on monetary stability as a central bank's main target. Kemmerer was even quoted in Niemeyer's report to Brazil regarding the need for central banks to avert 'undue political and governmental influence.' 109

\footnotetext{
${ }^{102}$ Sayers, The Bank of England, p. 522.

${ }^{103 ،}$ Central Banks in Latin America', 25 May 1933, BoEA, file OV188/1.

${ }^{104}$ Letter from Otto Niemeyer to Bertram Hornsby, 25 May 1933, BoEA, file OV188/1.

${ }^{105}$ 'Exposition of Motives of the Law Amending Law 25 of 1923', The Organic Law of the Bank of the Republic, SGMML, EKP, box 132, folder 5.

${ }^{106}$ Ibid., p. 3.

${ }^{107}$ Ibid.

${ }^{108}$ 'Report Submitted to the Brazilian Government, by Sir Otto Niemeyer, 4th July 1931', in BoEA, file OV9/294.

${ }^{109}$ Ibid.
} 
Niemeyer's visits to Argentina and Brazil generated heated debates among politicians and in the press. In the case of Brazil, Thiago Gambi argues that Finance Minister José Maria Whitaker did not in principle oppose the idea of establishing a central bank, while President Getúlio Vargas had been indifferent, given the lack of financial support from Britain. In the same circles there were also doubts about Brazil's capacity to establish a fixed exchange rate as well as the government's ability to balance its fiscal position. ${ }^{110}$ In the case of Argentina, debates on the different proposals to establish a central bank had begun in 1931, with one of the Congress' criticisms of Niemeyer's proposal being that it did not consider the delicate position of the (commercial) banks. ${ }^{111}$

Table 4 also shows the cases of El Salvador and Venezuela. In El Salvador, Frederick Francis Joseph Powell, who had assisted Niemeyer in his previous missions to Argentina and Brazil, had initially considered a currency board, although Niemeyer seems to have been opposed to one due to local politics. ${ }^{12}$ The mission recommended converting one of the issue banks, the Banco Agrícola Comercial (Commercial Agricultural Bank), to make it operate as a central bank under the same parameters as those proposed in Argentina and Brazil. A major innovation was the capacity of the central bank to provide credit to the coffee sector, as it was recognised that the country was very dependent upon its performance, and the bank's credit policy would therefore have an immediate impact on the monetary supply. ${ }^{113}$

In other countries, central banks had been modified and new credit programmes had been implemented. Chile is an illustrative example. Guillermo Subercaseaux, governor at the Banco Central de Chile (Central Bank of Chile) from 1933, had already expressed certain misgivings about orthodox central banks and also the gold standard. He claimed that the stability of a currency's purchasing power was relevant and could be pursued without adhering to the gold standard. ${ }^{114} \mathrm{He}$ also explained that the recommendations provided by Kemmerer during the Lima conference of 1931 regarding the use of open market operations to regulate the monetary base were not suitable for Latin American countries given the lack of development of banking acceptances, as was the case in the United States. In his opinion, undertaking open market operations of other financial assets with much more volatility was not advisable.

Chile's government had initiated attempts to boost the flow of credit to the industrial and agricultural sectors. Initially, the government had requested that the central bank provide low-interest credit to development institutions, even though this rendered the management of monetary policy difficult. This was

\footnotetext{
${ }^{110}$ Thiago Gambi, 'Las misiones inglesas y la (no) creación de un banco central en Brasil (1924/1931)', Anuario IEHS, 35: 2 (2020), pp. 199-220.

${ }^{111}$ Jorge A. Lorenzutti, Dinero, politica y bancos: Historia del Banco Central de la República Argentina 1935-1995 (Buenos Aires: Ediciones Dunken, 1996). The new central bank had to organise a bailout operation to support commercial banks in 1935. See Gerardo della Paolera and Alan M. Taylor, 'Internal versus External Convertibility and Emerging-Market Crises: Lessons from Argentine History', Explorations in Economic History, 39: 4 (2002), pp. 357-89.

${ }^{112}$ Sayers, The Bank of England, p. 524.

${ }^{113}$ 'Mr. Hawtrey's Comments on Mr. Powell's Report', Salvador, F. F. J. Powell's Mission, 11 May 1934, BoEA, file OV20/8.

${ }^{114}$ Guillermo Subercaseaux, Seis años de política monetaria (1933-1938) (Santiago: Universo, 1938), p. 8.
} 
Table 4. Central Banks Established during the 1930s: Niemeyer and Other Banks

\begin{tabular}{|c|c|c|c|c|c|}
\hline & $\begin{array}{l}\text { Argentina } \\
\text { (Prebisch) }\end{array}$ & $\begin{array}{c}\text { Argentina } \\
\text { (Niemeyer) } \\
7 \text { April } 1933\end{array}$ & $\begin{array}{c}\text { Brazil } \\
\text { (Niemeyer) } \\
\text { 4 July } 1931\end{array}$ & $\begin{array}{l}\text { El Salvador } \\
26 \text { July and } 9 \\
\text { September } \\
1933\end{array}$ & $\begin{array}{c}\text { Venezuela } \\
8 \text { September } 1939\end{array}$ \\
\hline \multicolumn{6}{|l|}{$\begin{array}{l}\text { Authorised } \\
\text { capital }\end{array}$} \\
\hline $\begin{array}{l}\text { (in millions } \\
\text { local } \\
\text { currency) }\end{array}$ & 30 & 15 & 60,000 & 1.65 & 10 \\
\hline $\begin{array}{l}\text { Duration } \\
\quad \text { (in years) }\end{array}$ & 40 & 40 & 30 & 30 & 50 \\
\hline \multicolumn{6}{|l|}{ Shareholding } \\
\hline $\begin{array}{l}\text { Total number } \\
\text { of shares }\end{array}$ & 30,000 & 15,000 & 300,000 & 50,000 & 100,000 \\
\hline Foreign banks & $\begin{array}{l}\text { All banks with a capital higher than } \\
1 \text { million obliged to subscribe } \\
\text { proportionally to their capital, until } \\
\text { reaching the equivalent of } 10 \\
\text { million. Remaining } 10 \text { million to be } \\
\text { subscribed by new banks }\end{array}$ & $\begin{array}{l}\text { All banks with a capital } \\
\text { higher than } 1 \text { million } \\
\text { obliged to subscribe } \\
\text { proportionally to their } \\
\text { capital }\end{array}$ & $\begin{array}{c}50 \% \text { of total shares; } \\
\text { no bank allowed to } \\
\text { have more than } 3 \% \text { of } \\
\text { the total amount of } \\
\text { capital }\end{array}$ & $\begin{array}{l}450,000 \\
\text { colones }\end{array}$ & \multirow{2}{*}{$\begin{array}{l}50 \% \text { to be } \\
\text { subscribed by the } \\
\text { public and banks, } \\
\text { without distinction }\end{array}$} \\
\hline Other & 0 & 0 & $\begin{array}{l}50 \% \text { of shares offered } \\
\text { to the public }\end{array}$ & $\begin{array}{l}1.2 \text { million } \\
\text { colones }\end{array}$ & \\
\hline
\end{tabular}


Table 4. (Continued.)

\begin{tabular}{|c|c|c|c|c|c|}
\hline & Argentina (Prebisch) & Argentina (Niemeyer) & Brazil & El Salvador & Venezuela \\
\hline \multicolumn{6}{|l|}{ Board of directors } \\
\hline Presidency & $\begin{array}{l}\text { President and a vice- } \\
\text { president }\end{array}$ & $\begin{array}{c}\text { President and a vice- } \\
\text { president }\end{array}$ & $\begin{array}{l}\text { President and a } \\
\text { vice-President }\end{array}$ & President & President \\
\hline $\begin{array}{l}\text { Total number of } \\
\text { members }^{a}\end{array}$ & 12 & 7 & 5 & 4 & 8 \\
\hline \multicolumn{6}{|l|}{ Appointed by: } \\
\hline State & 1 & - & 0 & 0 & 4 \\
\hline Domestic banks & 5 & 3 & \multirow[t]{2}{*}{2} & \multirow[t]{2}{*}{1} & \multirow{2}{*}{$\begin{array}{c}\text { 1, as representative } \\
\text { of the National } \\
\text { Banking Council }\end{array}$} \\
\hline Foreign banks & 2 & 2 & & & \\
\hline Agriculture & 1 & 1 & \multirow{3}{*}{$\begin{array}{l}3 \text { directors (from } \\
\text { persons engaged in } \\
\text { industrial, commercial } \\
\text { or agricultural } \\
\text { undertakings) }\end{array}$} & $\begin{array}{l}1 \text { (President of } \\
\text { Coffee Growers' } \\
\text { Association) }\end{array}$ & 0 \\
\hline Industry & 1 & 0 & & 0 & 0 \\
\hline Commerce & 1 & 0 & & 0 & 0 \\
\hline Trade unions & 0 & 0 & 0 & 0 & 0 \\
\hline Other & 1 (Livestock sector) & 1 (Livestock sector) & 0 & $\begin{array}{l}2 \text { (by the } \\
\text { organising } \\
\text { committee) }\end{array}$ & 3 \\
\hline $\begin{array}{l}\text { Reserve } \\
\text { requirements }\end{array}$ & $25 \%$ & $25 \%$ & $30 \%$ & $33 \%$ & $50 \%$ \\
\hline $\begin{array}{l}\text { Limit on } \\
\text { government } \\
\text { lending }\end{array}$ & $\begin{array}{l}\text { Only short-term loans up to } \\
10 \% \text { of tax revenues, } \\
\text { estimated as an average of } \\
\text { last three years and to be } \\
\text { reimbursed before } 31 \\
\text { December of each year }\end{array}$ & $\begin{array}{c}\text { Only short-term loans up } \\
\text { to } 10 \% \text { of tax revenues (to } \\
\text { be reimbursed before } 31 \\
\text { December of each year) } \\
\text { as budgeted by the } \\
\text { Congress }\end{array}$ & $\begin{array}{l}\text { Limit to one-eighth of } \\
\text { the revenues of the } \\
\text { previous year repaid } \\
\text { during the calendar } \\
\text { year }\end{array}$ & $\begin{array}{c}\text { Temporary } \\
\text { advances only } \\
\text { (10\% of customs } \\
\text { duties) - } \\
\text { revenues }\end{array}$ & Not allowed \\
\hline
\end{tabular}

Note: ${ }^{\text {a }}$ President and vice-president not included.

Sources: Argentina: Niemeyer, 'Informe'. Brazil and El Salvador: BoEA, files OV9/294 and OV20/8, respectively. Venezuela: Egaña, Documentos relacionados. 
illustrated by a credit request by a major nitrate company, the Compañía de Salitre de Chile (Chilean Nitrate Company, COSACH). This request triggered an intense debate within the directorate of the bank as to the advisability of continuing this credit policy, as it generated unnecessary increases in the monetary issue. ${ }^{115}$ The new banking law allowed the central bank to guarantee the credits granted by commercial banks to this sector, thereby reducing the interest rates attached to the loans and preventing the bank from using its own resources, ${ }^{116}$ which were those that were in excess of their reserve requirements at the central bank.

The case of Venezuela seems to have followed the same trend. As discussions were launched in 1937 to establish a central bank, a mission was sent to visit the United States, Canada, Argentina, Chile, Peru and Colombia. The head of Venezuela's mission, Minister of Development Manuel Egaña, considered that the Federal Reserve System did not offer a relevant example for Venezuela, contrary to that of Canada, whose economic structure was more similar to its own. Egaña was also critical of the design of central banks in Peru and Colombia. The mission to Chile met with Hermann Max, head of research at the central bank, who had been recommended as an advisor to Venezuela's government by Subercaseaux. Max was also a strong critic of the gold standard, and he insisted that the problem was not the structure of a central bank per se, but rather the international monetary system. When Venezuela created its own central bank in 1939, the main objective was defined as 'regulating the monetary supply to adjust it to the legitimate needs of the national market' and 'monitor the value of the currency, in terms of purchasing power and in relation to foreign currencies. ${ }^{117}$

\section{Conclusion}

The argument raised by Eichengreen and Peter Temin regarding the 'change of mentality' towards the gold standard delineated a global phenomenon that led to reforms and the emergence of new actors and ideas. ${ }^{118}$ As these authors note, a major policy reform in the United States was the 1935 Banking Act that sought to promote the 'stability of employment and business' and new actors were appointed to conduct the monetary policy of the country. In 1936, as discussions were taking place regarding candidates to become new members of the board of governors of the Federal Reserve, Kemmerer was suddenly dismissed. The prime reason for this was his allegiance 'to the old-fashioned gold-standard' while 'money doctor' to various nations. 'In this Depression he has only warned against inflation, never against deflation.'119

As this article demonstrates, money doctors did not revise their prescriptions given the new circumstances generated by the Great Depression. Even if Kemmerer's central banks succeeded in bringing a halt to extended periods of high inflation, they were unable to adapt to the changing needs of Latin American

\footnotetext{
${ }^{115}$ Banco Central de Chile, Actas 323 and 324, 13 and 17 Oct. 1932, respectively, CCBDR.

${ }^{116}$ Subercaseaux, Seis años de política monetaria, p. 7.

${ }^{117}$ 'Ley de Banco Central', in Manuel Egaña, Documentos relacionados con la creación del Banco Central de Venezuela (Caracas: Banco Central de Venezuela, 1979), p. 172.

${ }^{118}$ Barry Eichengreen and Peter Temin, 'The Gold Standard and the Great Depression', Contemporary European History, 9: 2 (2000), pp. 183-207.

${ }^{119}$ Unsigned memo addressed to US President Franklin D. Roosevelt, 16 Jan. 1936, Franklin D. Roosevelt Presidential Library and Museum, Franklin D. Roosevelt, Papers as President: The President's Secretary's File (PSF), box 134.
} 
economies. Kemmerer's commitment to monetary stability and the gold-exchange standard failed to adjust to the extraordinary events triggered by the world's economic crisis. As I have shown, the remedies proposed by Niemeyer were not radically different. The plans elaborated for Brazil and Argentina in the 1930s aimed for a return to the gold-exchange standard, without assigning the function of banking supervision to the central bank, which was envisaged as having a mostly passive role. In both cases, Niemeyer's proposals advised the establishment of central banks that resembled, to a large extent, their counterparts in Kemmerer countries.

In a sense, an implicit message of this article is that economic crises may also serve to implement innovative polices once it is evident that dominant paradigms have expired. Latin American economists, increasingly concerned with concrete problems, were well positioned to react to the particular conditions of the 1930s. For example, Prebisch, forced by the pressure of local and international circumstances to reject Niemeyer's advice, conceived a project that was intended to meet the urgent needs of the country, resulting in a bank that was allowed to conduct open market operations, supervised private banks and was primarily engaged in implementing counter-cyclical operations.

It is interesting to note that similar economic policies were being introduced in other countries. In Mexico, Manuel Gómez Morín, who participated in the conception of Mexico's central bank in 1925, championed the introduction of a new set of laws in 1932, some of which were intended to strengthen the relationship between the central bank and commercial banks by facilitating rediscount operations while others aimed at fostering private credit. ${ }^{120} \mathrm{He}$ would serve as foreign advisor to Ecuador in $1938 .{ }^{121}$ Max, a Chilean economist at the central bank who was critical of the gold standard, also advised Costa Rica (1936) and remained an advisor to Venezuela for several years. ${ }^{122}$ While the paths of Latin America's central banks and monetary systems maintained a strong degree of diversity in subsequent decades, we might consider these attempts at adapting foreign economic policies to local needs as foreshadowing subsequent institutional efforts that materialised with the founding of the Economic Commission for Latin America and the Caribbean (ECLAC) in 1948. This international body would later lead a collective effort to promote ideas and policies anchored in the region's economic and social context.

Acknowledgements. I thank Adriana Calcagno for her contribution to a first and preliminary draft of this article, and also Franco Lobo and Laura de la Villa Alemán for excellent research assistance. I am grateful for the comments received from Carlos Marichal, Eric Monnet, Gianandrea Nodari, from participants of the Seminar of International History at El Colegio de México in October 2018, from participants at the conference on 'The Birth of Central Banks: Building a New Monetary Order', held at the Bank of Greece, Athens, on November 2018, and three anonymous referees. I am also grateful to Aurora Gómez Galvarriato Freer for fruitful conversations on the history of Mexico's central bank, and Florencia Sember, Luis Salcedo Gutierrez and Guy Pierre for sharing primary sources and references. I am especially thankful for the kind cooperation of librarians at the Seeley G. Mudd Manuscript Library at Princeton University, Romina Oses at the Central Bank of Chile and archivists at the Bank of England Archives. The usual disclaimer applies. Financial support from Humanities in the European Research Area - HERA Joint Research Programme 3 'Uses of the Past' is gratefully acknowledged.

\footnotetext{
${ }^{120}$ Gómez-Galvarriato, 'La etapa inicial del Banco Central', p. 249.

${ }^{121}$ Marchán Romero, Historia del Banco Central del Ecuador, p. 55.

${ }^{122}$ Rodrigo Quesada Monge, Ideas económicas en Costa Rica (1850-2005) (San José: EUNED, 2008), p. 94.
} 


\section{Spanish abstract}

Muchos de los bancos centrales de América Latina se establecieron en el período de entreguerras. Durante la década de los veinte, la mayoría de ellos fueron diseñados bajo la influencia de consejeros extranjeros, también llamados médicos monetarios. El mandato principal de estas nuevas instituciones se enfocó en la disminución de la inflación y en la estabilidad cambiaria. Este artículo analiza cómo respondieron estos bancos centrales al inicio de la Gran Depresión. Mostramos que, de acuerdo con los requisitos del régimen monetario, los bancos centrales actuaron inicialmente para prevenir las salidas de capital y proteger sus reservas de oro. Esto provocó una caída del crédito al sector privado. Esta situación cambió una vez que los gobiernos decidieron intervenir más activamente en la economía, ignorando así los consejos de los médicos monetarios. Los bancos centrales que se fundaron en la década de 1930 fueron concebidos para hacer frente a los efectos de la crisis.

Spanish keywords: banca central; Gran Depresión; patrón oro; consejeros extranjeros; médicos monetarios; crisis financiera

\section{Portuguese abstract}

Muitos dos bancos centrais de hoje na América Latina foram estabelecidos no período entre guerras. Durante a década de 1920, a maioria deles foi projetada sob a influência de conselheiros estrangeiros, também chamados de médicos monetários. O principal mandato dessas novas instituições era lidar com a inflação e proporcionar estabilidade cambial. Este artigo analisa como esses bancos centrais responderam ao início da Grande Depressão. Mostro que, de acordo com as exigências do regime monetário, os bancos centrais agiram inicialmente para evitar fugas de capitais e proteger suas reservas de ouro. Isso levou a uma queda do crédito ao setor privado. Crédito adicional foi disponibilizado quando os governos decidiram intervir mais ativamente na economia, desconsiderando, assim, o conselho dos médicos monetários. Os bancos centrais fundados na década de 1930 e as reformas introduzidas naqueles que já operavam foram concebidos para fazer frente aos efeitos da crise.

Portuguese keywords: banco central; Grande Depressão; padrão-ouro; médicos monetários; crises financeiras

Cite this article: Flores Zendejas J (2021). Money Doctors and Latin American Central Banks at the Onset of the Great Depression. Journal of Latin American Studies 53, 429-463. https://doi.org/10.1017/ S0022216X21000444 